\title{
Deeply subducted continental fragments - Part 2: Insight from petrochronology in the central Sesia Zone (western Italian Alps)
}

\author{
Francesco Giuntoli, Pierre Lanari, Marco Burn, Barbara Eva Kunz, and Martin Engi \\ Institute of Geological Sciences, University of Bern, Baltzerstrasse 1 + 3, 3012 Bern, Switzerland \\ Correspondence: Francesco Giuntoli (francesco.giuntoli@gmail.com)
}

Received: 11 August 2017 - Discussion started: 4 September 2017

Revised: 13 December 2017 - Accepted: 12 January 2018 - Published: 26 February 2018

\begin{abstract}
Subducted continental terranes commonly comprise an assembly of subunits that reflect the different tectono-metamorphic histories they experienced in the subduction zone. Our challenge is to unravel how, when, and in which part of the subduction zone these subunits were juxtaposed. Petrochronology offers powerful tools to decipher pressure-temperature-time $(P-T-t)$ histories of metamorphic rocks that preserve a record of several stages of transformation. A major issue is that the driving forces for reequilibration at high pressure are not well understood. For example, continental granulite terrains subducted to mantle depths frequently show only partial and localized eclogitization. The Sesia Zone (NW Italy) is exceptional because it comprises several continental subunits in which eclogitic rocks predominate and high-pressure (HP) assemblages almost completely replaced the Permian granulite protoliths. This field-based study comprises both main complexes of the Sesia terrane, covering some of the recently recognized tectonic subunits involved in its assembly; hence our data constrain the HP tectonics that formed the Sesia Zone. We used a petrochronological approach consisting of petrographic and microstructural analysis linked with thermodynamic modelling and $\mathrm{U}-\mathrm{Th}-\mathrm{Pb}$ age dating to reconstruct the $P-T-t$ trajectories of these tectonic subunits. Our study documents when and under what conditions re-equilibration took place. Results constrain the main stages of mineral growth and deformation, associated with fluid influx that occurred in the subduction channel. In the Internal Complex (IC), pulses of fluid percolated at eclogite facies conditions between 77 and $55 \mathrm{Ma}$ with the HP conditions reaching $\sim 2 \mathrm{GPa}$ and 600 $670^{\circ} \mathrm{C}$. By contrast, the External Complex (EC) records a lower pressure peak of $\sim 0.8 \mathrm{GPa}$ for $500^{\circ} \mathrm{C}$ at $\sim 63 \mathrm{Ma}$. The juxtaposition of the two complexes occurred during exhuma-
\end{abstract}

tion, probably at $\sim 0.8 \mathrm{GPa}$ and $350^{\circ} \mathrm{C}$; the timing is constrained between 46 and $38 \mathrm{Ma}$. Mean vertical exhumation velocities are constrained between 0.9 and $5.1 \mathrm{~mm}_{\text {year }}{ }^{-1}$ for the IC, up to its juxtaposition with the EC. Exhumation to the surface occurred before $32 \mathrm{Ma}$, as constrained by the overlying Biella Volcanic Suite, at a mean vertical velocity between 1.6 and $4 \mathrm{~mm}_{\text {year }}{ }^{-1}$. These findings constrain the processes responsible for the assembly and exhumation of HP continental subunits, thus adding to our understanding of how continental terranes behave during subduction.

\section{Introduction}

The behaviour of continental crust subducted to highpressure (HP) conditions is far from fully understood (Rubatto and Hermann, 2001; Brun and Faccenna, 2008; Kylander-Clark et al., 2008; Malusà et al., 2011; Angiboust et al., 2017). Seismic tomography beneath collisional orogens shows that large slab parts reached mantle depths (e.g. Lippitsch et al., 2003; Replumaz et al., 2010; Zhao et al., 2015), but the source of such remnants is hard to assess because the rocks cannot be directly investigated. However, orogens that contain exhumed continental HP rocks offer opportunities to investigate some of the tectono-metamorphic processes involved, notably those responsible for the return flow of continental fragments back to the surface.

In recent studies on the western Alps, the combination of tectonic and numerical modelling studies (e.g. Yamato et al., 2008; Faccenda et al., 2009) with the reconstruction of pressure-temperature-time $(P-T-t)$ paths (e.g. Rubatto et al., 2011; Regis et al., 2014) has led to two possible endmember scenarios for the subduction of continental domains to 
HP conditions. The units could have essentially experienced tectonic slicing, followed by accretion to overlying continental units, thus assembling complexes composed of different tectono-metamorphic slices (e.g. Vitale Brovarone et al., 2013; Angiboust et al., 2014; Manzotti et al., 2014; Regis et al., 2014). Alternatively, units could have been eroded or ablated in the subduction channel, which lost coherence and experienced substantial mixing, leading to diverse and complex $P-T-t$ paths (e.g. Tao and O'Connell, 1992; Stöckhert and Gerya, 2005; Warren et al., 2008; Keppie et al., 2009; Roda et al., 2012). The distinction between these two endmember scenarios is important to understand the evolution of deeply subducted continental domains and possibly their palaeogeographic provenance.

Crucial questions related to continental HP units in orogens include the following: how rapidly were they subducted and to what depth? When and how fast were they exhumed? What $P-T-t$ trajectories did they experience? When and how did fluids affect these continental fragments? To shed light on these questions, the sequence of metamorphic stages recorded in suitable samples needs to be analysed in detail (Engi et al., 2017). $P-T-t$ paths promise insight into details of these fundamental tectonic processes. Petrochronological studies in the western Alps have helped to constrain exhumation rates of Alpine HP and ultra-HP continental domains. Calculated rates vary from a few millimetres (e.g. Zucali et al., 2002; Regis et al., 2014, for the internal part of the Sesia Zone, SZ) to a few centimetres per year (e.g. Rubatto and Hermann, 2001, for Dora Maira ultra-HP massif). In detail, some studies found that, after a first phase of rapid exhumation up to lower crustal levels, exhumation rates markedly decreased to a few millimetres per year (Rubatto and Hermann, 2001; Yamato et al., 2008).

Generally speaking, how much of the subduction history is recorded in a sample is related to what processes triggered mineral recrystallization or equilibration. Several studies (e.g. Etheridge et al., 1983; Rubie, 1986; Austrheim, 1987; Erambert and Austrheim, 1993; Oliver, 1996; Pennacchioni, 1996; Engi et al., 2018) proposed that fluid influx triggers deformation and mineral reactions in deeply subducted high-grade (granulite and amphibolite facies) domains. It is of interest to know when this happened in the $P-T-t$ evolution, notably whether it occurred early, during subduction, or only late, upon exhumation (e.g. Konrad-Schmolke et al., 2011).

We present a field-based study emphasizing $P-T-t$ data and discuss their implications on such first-order questions. Datasets from a well-defined multidimensional analysis, i.e. pressure-temperature-time-deformation-space, are essential as a reference frame for numerical modelling studies. Our petrochronological approach highlights the complex and heterogeneous tectono-metamorphic evolution in a polydeformed continental terrane. A key requirement in this approach is to establish reliable links between age data $(t)$ and the $P-T$ conditions of mineral formation (e.g. Buick and
Holland, 1989; Schenk, 1989; Scott and St-Onge, 1995; Liati and Gebauer, 1999; Rubatto and Hermann, 2001; Foster et al., 2004; Janots et al., 2009; Rubatto et al., 2011; Gasser et al., 2012; Donaldson et al., 2013; Mottram et al., 2014; Regis et al., 2014). In this study, mutual inclusion relationships of the main mineralogical phases in the datable accessory minerals, along with microstructural analyses, were used to bracket mineral age data to $P-T$ conditions. The study area is the central SZ, located in the western Alps (Aosta Valley, Italy). $P-T-t$ data are reconstructed for the eclogite facies Internal Complex (IC) and, for the first time, for the epidote blueschist facies External Complex (EC). These data allow us to constrain the juxtaposition of the two complexes, which occurred under HP greenschist facies conditions, and to determine exhumation rates for the IC and for the assembly of the SZ.

\section{Geological setting}

The Alps are an orogen that has developed since the Cretaceous due to the subduction of the European Plate below the Adriatic Plate, with subsequent continental collision (e.g. Dewey et al., 1989; Rosenbaum et al., 2002; Beltrando et al., 2010; Handy et al., 2010; Schmid et al., 2017). The SZ is located in the western Alps (Fig. 1a) and regarded as a rifted portion of the Adriatic Margin that experienced subduction to HP conditions (e.g. Dal Piaz, 1999). At present, it is bounded by two tectonic lineaments: the Insubric Line to the SE and the Gressoney Shear Zone to the NW. The Insubric Line is a major fault system of Oligocene-Neogene age that separates the SZ from the southern Alpine domain, which represents the Adriatic Margin and shows but a weak Alpine imprint at sub-greenschist facies. An important complex in the southern Alps is the Ivrea Zone, consisting of amphibolite to granulite facies metasediments, mantle peridotites, and mafic intrusives. It is proposed to represent a cross section through the lower pre-Alpine crust (e.g. Bertolani, 1954, 1959; Rivalenti et al., 1975; Zingg, 1983; Quick et al., 2003). Analogies between the pre-Alpine metamorphism of the IC (Giuntoli and Engi, 2016) of the SZ and the Ivrea Zone have been repeatedly emphasized (e.g. Dal Piaz et al., 1972; Compagnoni et al., 1977). The Gressoney Shear Zone is a greenschist shear zone (e.g. Wheeler and Butler, 1993; Babist et al., 2006) that separates the SZ from units derived from the PiemonteLiguria Ocean that experienced blueschist-to-eclogite facies metamorphism during the Alpine orogeny (e.g. Bucher et al., 2005; Negro et al., 2013).

Recently, the central Sesia Zone has been subdivided into an IC and an EC (Giuntoli and Engi, 2016; Fig. 1b, c). The IC corresponds, as a whole, to the Eclogitic Micaschist complex of Williams and Compagnoni (1983) and Passchier et al. (1981). In detail, however, the IC comprises several eclogitic sheets with a thickness of a few kilometres, each of them characterized by an alternance of bands and elongate bodies of mica schist, eclogite, ortho- and paragneiss, and 

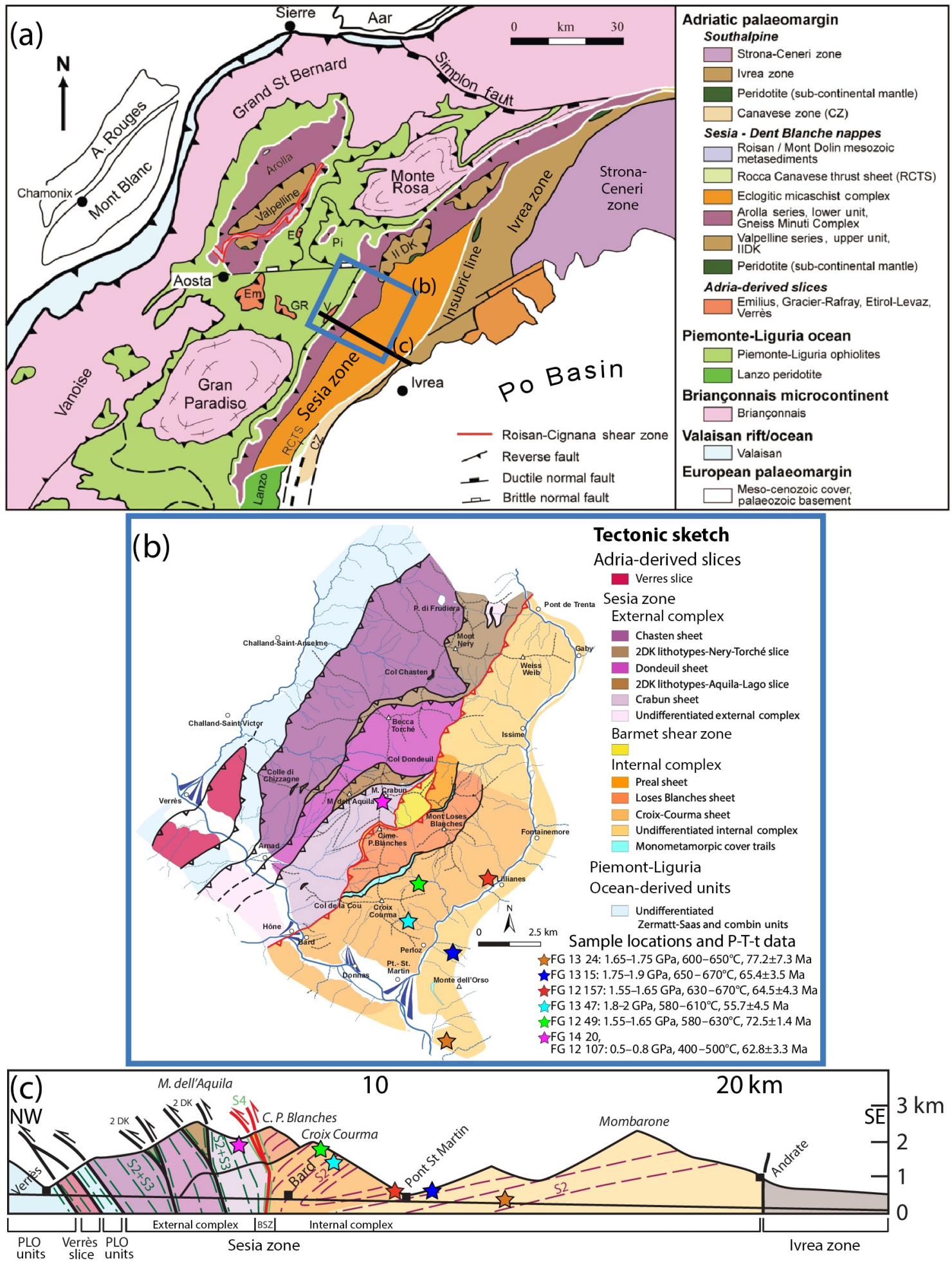

Figure 1. (a) Simplified tectonic map of the western Alps (modified from Manzotti et al., 2014). (b) Tectonic sketch of the study area (modified from Giuntoli and Engi, 2016) with sample locations and $P-T-t$ data (this study). (c) Cross section through the study area (location shown in a) with projection of the studied samples. Foliation traces: violet indicates the eclogite facies foliation (S2) of the IC, dark green indicates the composite epidote blueschist-HP greenschist facies foliation $(\mathrm{S} 2+\mathrm{S} 3)$ of the EC, and dark green indicates the greenschist facies mylonitic foliation (S4) at the IC-EC contact. BSZ: Barmet Shear Zone; PLO: Piemonte-Liguria oceanic unit (modified from Giuntoli and Engi, 2016). 
leucogneiss. The main foliation of this complex is of eclogite facies. Several deformation phases locally overprint this foliation at retrograde blueschist and greenschist facies conditions (details in Giuntoli and Engi, 2016).

The EC corresponds to the Gneiss Minuti and the 2DK complexes of previous authors. It comprises kilometrethick tectonic sheets of leuco- to mesocratic orthogneiss with minor paragneiss, calc-mica schist, impure quartzite, and marble separated by lenses preserving Permian hightemperature (HT) metamorphic relics (2DK; Carraro et al., 1970; Dal Piaz et al., 1971; Giuntoli and Engi, 2016). The main composite foliation reflects HP greenschist, at most epidote blueschist facies; these are the highest Alpine metamorphic conditions recorded by this complex. The HP foliation is affected by subsequent greenschist facies deformation. Juxtaposition of the two complexes involved a greenschist facies shear zone (Barmet Shear Zone in Giuntoli and Engi, 2016); the subunits in each complex are thin sheets that range in thickness from 0.5 to $3 \mathrm{~km}$.

Based on $P-T-t$ paths determined by petrochronological techniques, Rubatto et al. (2011) and Regis et al. (2014) recognized two tectono-metamorphic subunits in the IC: a more internal subunit, called Druer slice, experienced eclogite facies conditions with a pressure of 1.9-2 GPa and temperatures of $\sim 550{ }^{\circ} \mathrm{C}$ at around $85 \mathrm{Ma}$, then followed by exhumation. A more external subunit, called Fondo slice, experienced a first stage at eclogite facies, with pressures of 1.7$1.8 \mathrm{GPa}$ and temperatures between 520 and $550^{\circ} \mathrm{C}$ at around $75 \mathrm{Ma}$, then followed by an intermediate lower-pressure stage $\left(P<1.6 \mathrm{GPa}\right.$ and $\left.T<520^{\circ} \mathrm{C}\right)$ at around $68 \mathrm{Ma}$, and a second HP stage $\left(P=1.4-2 \mathrm{GPa}\right.$ and $\left.\sim 550^{\circ} \mathrm{C}\right)$ at around $65 \mathrm{Ma}$, followed by retrograde decompression. For the EC in the central Sesia Zone, no $P-T-t$ data are available so far.

A number of studies have produced additional age data for the Sesia Zone, using various methods, notably for the U$\mathrm{Th}-\mathrm{Pb}, \mathrm{Rb}-\mathrm{Sr}$, and $\mathrm{Ar}-\mathrm{Ar}$ systems; results are summarized in Table 1 of Compagnoni et al. (2014). These age data span from 85 to $62 \mathrm{Ma}$ for the eclogite facies metamorphism in the IC, but apart from those detailed above, none of the datasets report detailed links to petrogenetic conditions. A few age data are available for the EC, ranging from 46 to $38 \mathrm{Ma}$, and these are generally linked to the greenschist facies imprint (Compagnoni et al., 2014, and references therein).

\section{Sampling strategy and petrochronological approach}

To document the polyphase history of the Sesia Zone, we reconstructed detailed $P-T-t$ paths for five samples taken in the IC and two samples in the EC. Of over 100 samples checked, a very small percentage fulfilled the requirements for such a study. In the EC, in particular, suitable material to quantify $P-T-t$ conditions using the present methods turned out to be very rare. This is mostly due to the fact that orthogneiss, the dominant rock type in the EC, is lacking in minerals suitable to obtain the Alpine $P-T-t$ path, as dis- cussed by Giuntoli and Engi (2016). Nevertheless, the samples analysed provide constraints to derive a $P-T-t$ path for the EC as well, allowing us to determine when and at what conditions the two complexes were juxtaposed.

All samples were taken in key areas of the mapped structures and were collected oriented, in order to keep the link between the meso- and microstructural evidence. Samples were carefully studied using optical and (where needed) scanning electron microscopy (SEM) to reconstruct their microstructural and metamorphic evolution. Once a relative chronology was established, selected growth zones of mineral phases were analysed with an electron probe microanalyser (EPMA) as a basis to perform thermodynamic modelling. $P-T$ data were linked to fabric elements, using textural criteria. Geochronology was performed with laser ablation inductively coupled plasma mass spectrometry (LA-ICP-MS), targeting specific growth zones of accessory phases that were separated after noting their microstructural and geochemical context. It turned out to be critical to analyse each growth zone separately to link the age $(t)$ to a specific metamorphic stage $(P-T)$. Observations and $P-$ $T-t$ data derived from each sample are then compared and correlated within the sample series and then related to observations made in the field data and in microscopy. This detailed petrochronological approach (e.g. Engi et al., 2017) is particularly effective when applied to a study area that has been mapped and structurally characterized in detail, as in the present case.

\section{Petrography and mineral chemistry}

\subsection{Methods}

\subsubsection{SEM}

Backscattered electron images (BSEs) were acquired using the Zeiss EVO50 SEM at the Institute of Geological Sciences (University of Bern) using an accelerating voltage of 15 to $25 \mathrm{KeV}$, a beam current of $500 \mathrm{pA}$, and a working distance of $10 \mathrm{~mm}$. Cathodoluminescence (CL) pictures were obtained with the same operative conditions but with $10 \mathrm{KeV}$ accelerating voltage and a working distance of $9.5 \mathrm{~mm}$.

\subsubsection{EPMA analyses}

EPMA analyses were performed using a JEOL JXA-8200 superprobe at the Institute of Geological Sciences (University of Bern). Point-mode analyses and X-ray compositional maps were acquired using wavelength-dispersive spectrometers. For X-ray mapping the procedure described in Lanari et al. (2013) was followed. It consists in measuring point-mode analyses first and then acquiring X-ray compositional maps on the same area. For point analyses, analytical conditions included $15 \mathrm{KeV}$ accelerating voltage, 10 to $20 \mathrm{nA}$ specimen current, $40 \mathrm{~s}$ dwell times (including $2 \times 10 \mathrm{~s}$ of background 


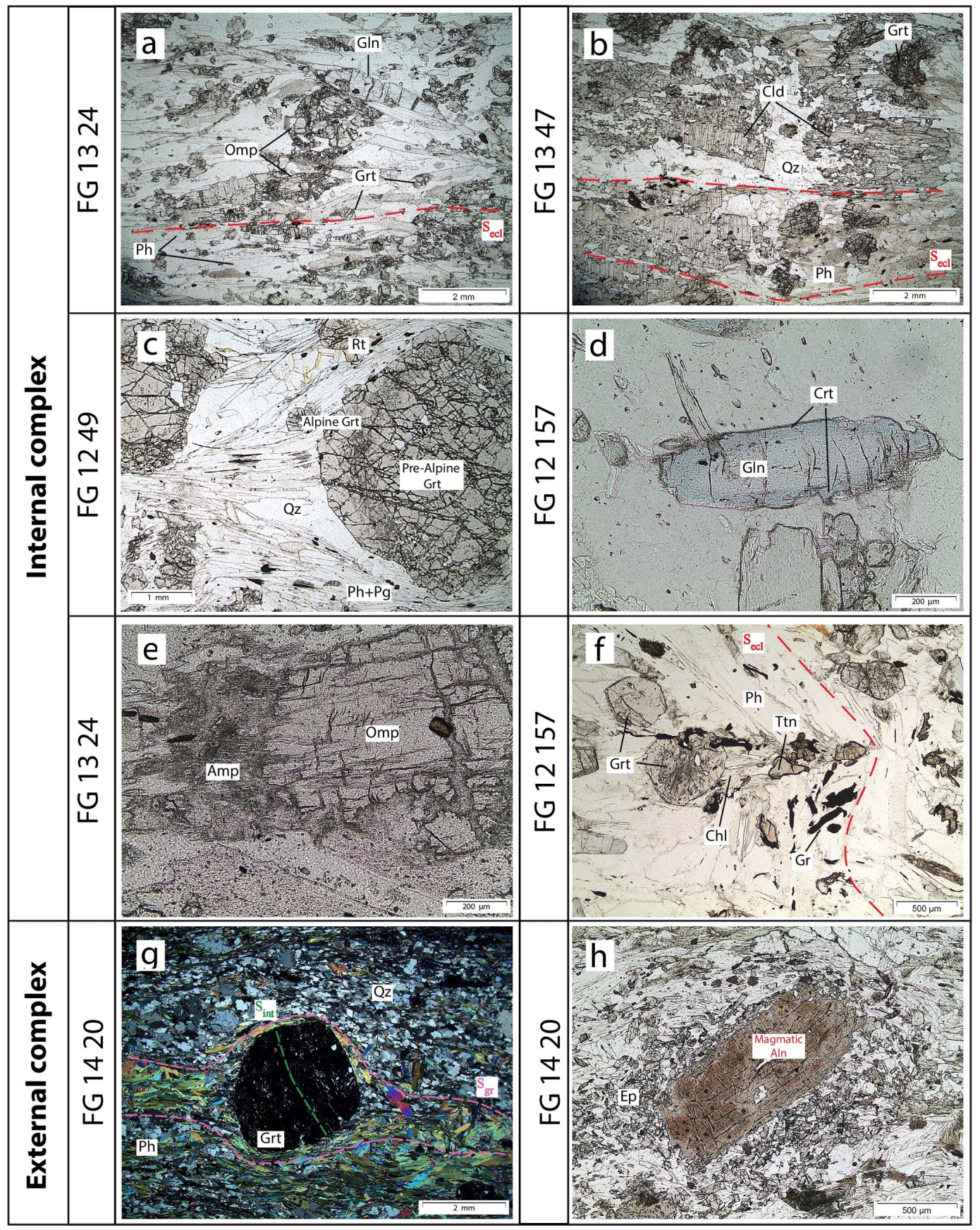

Figure 2. Thin-section photos illustrating the metamorphic evolution of the studied samples. Endmember mineral abbreviations used throughout text and figures are from Whitney and Evans (2010). (a) Eclogite foliation $\left(S_{\text {ecl }}\right)$ marked by subparallel phengite, omphacite, and glaucophane (plane-polarized light). (b) Eclogite foliation marked by the preferred orientation of chloritoid and phengite. Note the chloritoid crystal (left) is oriented perpendicular to $S_{\text {ecl }}$ and overgrows it (plane-polarized light). (c) Garnet crystal with a bright pre-Alpine core and darker Alpine rims visible due to fine rutile inclusions (plane-polarized light). (d) Glaucophane crystal with a core displaying pale blue absorption colour, rimmed by darker blue crossite that marks a retrograde blueschist stage (plane-polarized light). (e) Colourless to pale green amphibole growing at the expense of omphacite during a retrograde greenschist stage (plane-polarized light). (f) Open folds with chlorite crystallizing in the hinge zone, marking a retrograde greenschist stage (plane-polarized light). (g) Garnet porphyroclast wrapped by the main greenschist foliation $\left(S_{\mathrm{gr}}\right.$; note the inner foliation inside the garnet ( $S_{\mathrm{int}}$; crossed-polarized light). (h) Brown magmatic allanite surrounded by epidote crystals with smaller grain size (plane-polarized light). 


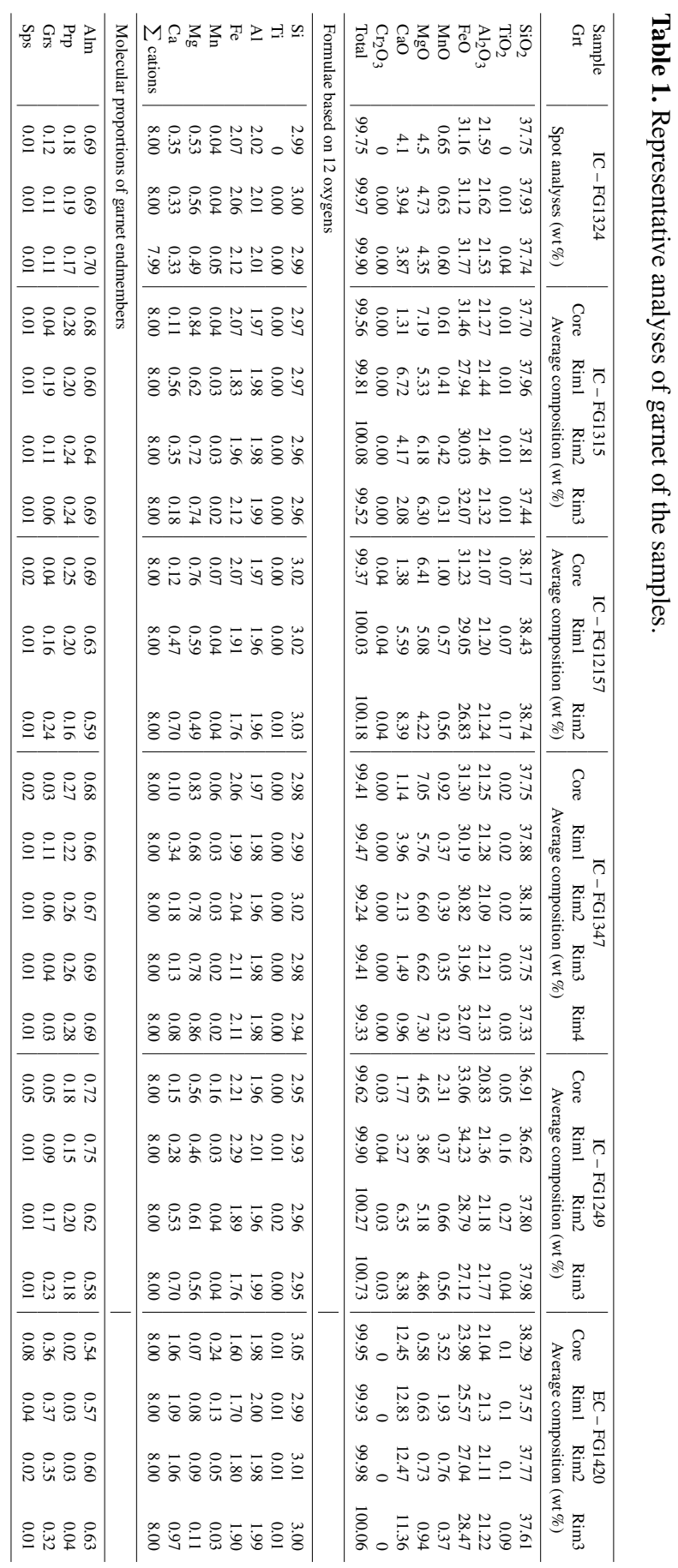

measurement), and a beam $\emptyset$ from 1 to $5 \mu \mathrm{m}$. Lower current and higher beam size were used for minerals containing $\mathrm{Ca}$, $\mathrm{Na}$, and $\mathrm{K}$ such as phengite and plagioclase. Nine oxide compositions were measured, using synthetic and natural standards: wollastonite-orthoclase-almandine $\left(\mathrm{SiO}_{2}\right)$, anorthitealmandine $\left(\mathrm{Al}_{2} \mathrm{O}_{3}\right)$, anorthite $(\mathrm{CaO})$, almandine $(\mathrm{FeO})$, forsterite-spinel $(\mathrm{MgO})$, orthoclase-phlogopite $\left(\mathrm{K}_{2} \mathrm{O}\right)$, albite $\left(\mathrm{Na}_{2} \mathrm{O}\right)$, ilmenite $\left(\mathrm{TiO}_{2}\right)$, and tephroite $(\mathrm{MnO})$. For $\mathrm{X}$ ray maps, analytical conditions included $15 \mathrm{KeV}$ accelerating voltage, $100 \mathrm{nA}$ specimen current, and dwell times of 150-250 ms. Nine elements ( $\mathrm{Si}, \mathrm{Ti}, \mathrm{Al}, \mathrm{Fe}, \mathrm{Mn}, \mathrm{Mg}, \mathrm{Na}$, $\mathrm{Ca}$, and $\mathrm{K}$ ) were measured at the specific wavelength in two passes. Intensity X-ray maps were standardized to concentration maps of oxide weight percentage using spot analyses as the internal standard. X-ray maps were processed using XMapTools 2.2.1 (Lanari et al., 2014).

\subsection{Results: sample description}

Five samples from the IC and two samples from the EC were analysed. These were collected from internal (SE) to external areas (NW) of the Sesia Zone. A brief account is given here, with characteristic images shown in Fig. 2. Supplement S1 contains detailed descriptions and GPS locations.

The samples of the IC (FG1324, FG1315, FG12157, FG1347, and FG1249) are mica schists with eclogite facies assemblages comprising quartz, phengite, garnet, \pm paragonite \pm glaucophane \pm omphacite \pm chloritoid, with accessory allanite \pm rutile. The main fabric in all of these samples is an eclogite facies foliation (Fig. 2a). Evidence of several deformation stages occurring before or after the main eclogite facies foliation is preserved in several samples as microlithons, commonly of phengite, omphacite, glaucophane, or chloritoid oriented at high angles relative to the main foliation, which wraps around them or is overgrown by them (Fig. 2b). Further evidence of several metamorphic stages occurring at eclogite facies conditions is reflected in growth zones of garnet (Giuntoli et al., 2018). Pre-Alpine relics include garnet cores (Fig. 2c) and zircon (cores \pm first rims; Sect. 6.4 and 6.5).

Retrograde stages of blueschist or greenschist facies assemblages related to decompression are locally present in samples. The blueschist facies stage produced pleochroic crossite rims around glaucophane (Fig. 2d). The greenschist facies stage produced symplectites of actinolite \pm albite \pm chlorite around glaucophane and omphacite, chlorite at the expense of garnet, epidote, or clinozoisite rims around allanite, and titanite rims formed around rutile (Fig. 2e, f).

Sample FG1420, collected in the EC, is a garnet orthogneiss that shows a HP greenschist foliation marked by phengite, chlorite, and titanite; the foliation wraps garnet porphyroblasts that preserve a relic internal foliation (Fig. 2g). Permian magmatic relics of pleochroic allanite are surrounded by an Alpine corona of epidote grains 
(Fig. 2h). Some hundred metres to the north, another sample (FG12107) of the EC was collected. This is a leucogneiss characterized by the same metamorphic fabric and parageneses as the previous sample, except that garnet and magmatic allanite are missing.

\subsection{Results: growth zones of garnet and phengite}

Garnet and phengite display features in the IC samples that differ from those in the EC samples. To highlight and describe these, two main samples are compared in the following paragraphs: FG1249 (IC) and FG1420 (EC). A more complete account of garnet textures and mineral inclusions in the IC is shown in Giuntoli et al. (2018).

In the IC samples, garnet consists of a core followed by several rims with a grain size of up to several millimetres (Fig. 3a, b). The compositional map of the grossular endmember fraction $\left(X_{\text {Grs }}\right)$ in sample FG1249 shows a porphyroclastic core $\left(\mathrm{Alm}_{72} \mathrm{Prp}_{18} \mathrm{Grs}_{5} \mathrm{Sps}_{5}\right.$; Table 1) with internal fractures sealed by garnet of higher $X_{\text {Grs }}$ (Fig. 3b). A first rim (Rim1- $\operatorname{Alm}_{76} \operatorname{Prp}_{15} \mathrm{Grs}_{9}$ ) overgrows the core and displays higher grossular contents. This Rim1 is followed by Rim2, which again records an increase in $X_{\mathrm{Grs}}\left(\mathrm{Alm}_{62} \operatorname{Prp}_{20} \mathrm{Grs}_{18}\right)$. Rim2 resorbs parts of Rim1, externally and internally, and the core. Rim3 is peripheral and shows the highest Ca contents $\left(\mathrm{Alm}_{58} \operatorname{Prp}_{19} \mathrm{Grs}_{23}\right)$.

Sample FG1315 is characterized by a porphyroclastic core $\left(\mathrm{Alm}_{69} \mathrm{Prp}_{28} \mathrm{Grs}_{4}\right)$ with lobate edges and resorption features (details in Giuntoli et al. 2018 and Engi et al. 2018) surrounded by several rim generations: Rim 1 $\left(\mathrm{Alm}_{61} \operatorname{Prp}_{21} \mathrm{Grs}_{19}\right)$, Rim2 (Alm $\left.65 \operatorname{Prp}_{24} \mathrm{Grs}_{11}\right)$, and Rim3 $\left(\mathrm{Alm}_{70} \mathrm{Prp}_{24} \mathrm{Grs}_{6}\right)$. Atoll garnets, a few hundred microns in size, are observed in this sample. The shells of the atoll garnet have similar zoning patterns and compositions as the rim generations just described. In sample FG12157 the garnet core $\left(\mathrm{Alm}_{70} \mathrm{Prp}_{26} \mathrm{Grs}_{4}\right)$ is rimmed by two growth zones: Rim1 (Alm $\left.{ }_{64} \operatorname{Prp}_{20} \mathrm{Grs}_{16}\right)$ and $\operatorname{Rim} 2\left(\mathrm{Alm}_{59} \mathrm{Prp}_{24} \mathrm{Grs}_{17}\right)$. In sample FG1347, the garnet core $\left(\mathrm{Alm}_{69} \mathrm{Prp}_{28} \mathrm{Grs}_{3}\right)$ is enclosed by three rims (Rim1: $\operatorname{Alm}_{66} \operatorname{Prp}_{23} \mathrm{Grs}_{11}$; Rim2: $\mathrm{Alm}_{68} \operatorname{Prp}_{26} \mathrm{Grs}_{6}$; Rim3: $\left.\mathrm{Alm}_{70} \mathrm{Prp}_{26} \mathrm{Grs}_{4}\right)$. The exception is sample FG1324, in which garnet shows a single growth zone of homogeneous composition ( $\mathrm{Alm}_{70} \mathrm{Prp}_{18} \mathrm{Grs}_{11} \mathrm{Sps}_{1}$ ).

In the EC, sample FG1420 shows garnet with completely different features. As shown in Fig. 3d, the $X_{\text {Sps }}$ map highlights concentric zoning (values of $\mathrm{Alm}_{54} \operatorname{Prp}_{2} \mathrm{Grs}_{36} \mathrm{Sps}_{8}$ for the core, $\mathrm{Alm}_{57} \mathrm{Prp}_{3} \mathrm{Grs}_{37} \mathrm{Sps}_{4}$ for Rim1, $\quad \mathrm{Alm}_{60} \mathrm{Prp}_{3} \mathrm{Grs}_{35} \mathrm{Sps}_{2}$ for Rim2, and $\mathrm{Alm}_{63} \operatorname{Prp}_{4} \mathrm{Grs}_{32} \mathrm{Sps}_{1}$ for Rim3), with no visible resorption features (further compositional endmember maps are shown in Supplement S2).

To link the growth zones of garnet to the main assemblage observed in the mineral matrix, microstructural relations, overprinting criteria, and mutual inclusions were employed, based on optical microscopy, SEM, and compositional maps. In particular, garnet in sample FG1249 contains inclusions of paragonite, phengite, and quartz between Rim1 and Rim2 (Fig. 3a). Rutile inclusions of a few microns are present in Rim2 and 3. Late chlorite fractures dissect the entire garnet. Garnet in sample FG1420 is wrapped by the main external foliation and includes an internal foliation marked by quartz, epidote, and titanite (Fig. 3c).

Phengite in IC samples displays a uniform composition except along grain boundaries, where lower $\mathrm{Si}$ and $X_{\mathrm{Mg}}$ contents are found, indicating retrograde overprinting (e.g. Fig. 3e; Group1 $\mathrm{Si} \sim 3.36$ apfu (atoms per formula unit), $X_{\mathrm{Mg}} \sim 0.83$; Group2 $\mathrm{Si} \sim 3.3 \mathrm{apfu}, X_{\mathrm{Mg}} \sim 0.68$ in sample FG1249; Table 2).

In the EC, two distinct generations of phengite are distinguished based on their microtextural position: the first one describes the main foliation and is characterized by high $\mathrm{Si}$ values (Fig. 3f; Group1 $\mathrm{Si} \sim 3.4 \mathrm{apfu}, X_{\mathrm{Mg}} \sim 0.61$ in sample FG1420), and the second phengite generation (Group2 $\mathrm{Si} \sim 3.32$ apfu, $\left.X_{\mathrm{Mg}} \sim 0.61\right)$ rims the first one and occurs in fold hinges that deform the main foliation.

\section{Thermobarometry}

\subsection{Methods}

\subsubsection{Whole-rock major element compositions}

Major element compositions were analysed using X-ray fluorescence (XRF) spectrometry at the University of Lausanne (Switzerland). Representative quantities of samples were crushed and then pulverized in a tungsten carbide mill. The powder was dried for $2 \mathrm{~h}$ at $105^{\circ} \mathrm{C}$. Loss of ignition was then determined by weight difference after heating to $1050^{\circ} \mathrm{C}$ for $3 \mathrm{~h}$.

\subsubsection{Garnet thermobarometry using GrtMod}

Garnet growth zones were carefully selected after detailed microstructural and compositional analysis of the highresolution X-ray maps to extract representative compositions that are used as input for modelling. Following the strategy proposed by Lanari et al. (2017), the composition of each growth zone was obtained directly from the quantitative maps by sampling chemically homogeneous areas amongst different garnet grains. Each composition was then assigned to a specific growth zone that is assumed to be uniform in the following. The regularity of the chemical zoning observed in garnet (Giuntoli et al., 2018) supports the grain boundary equilibrium model adopted here (Lanari and Engi, 2017). Minor heterogeneities observed in each growth zone $(<0.01$ in XAlm and XGrs; $<0.005$ in XPrp and XSps) may be due to kinetic effects during growth; they do not affect the results of the equilibrium model.

To model the complex garnet textures adequately, fractionation and resorption processes must be taken into account in approximating the evolution of the reactive bulk compo- 

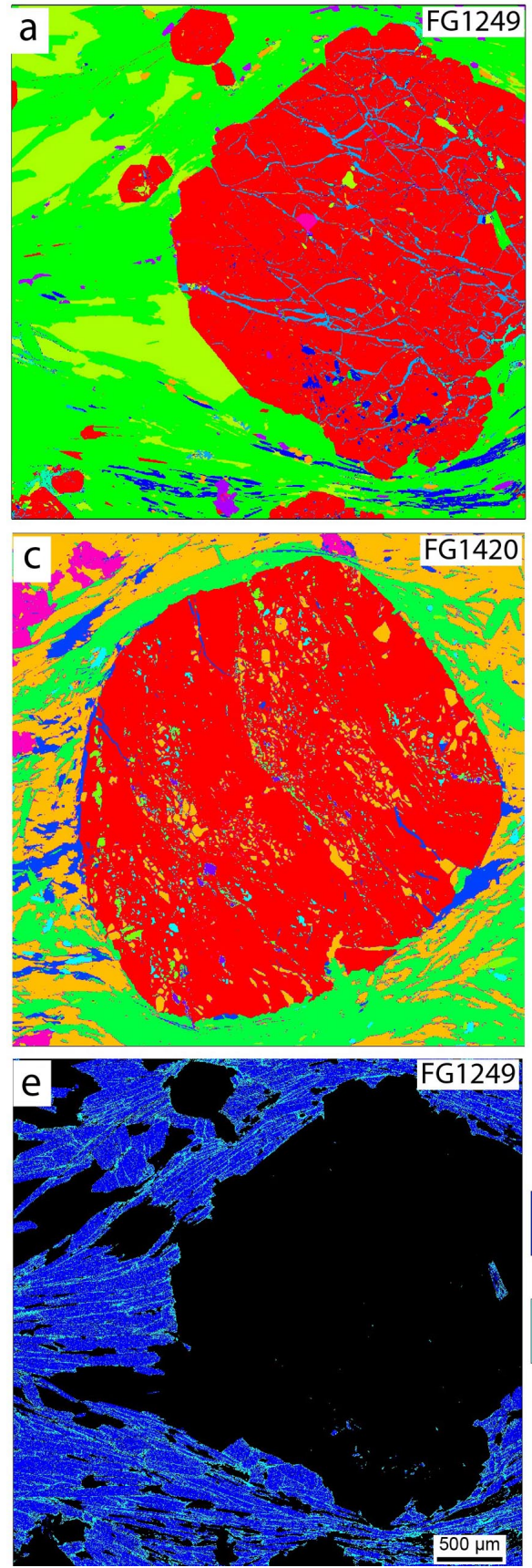
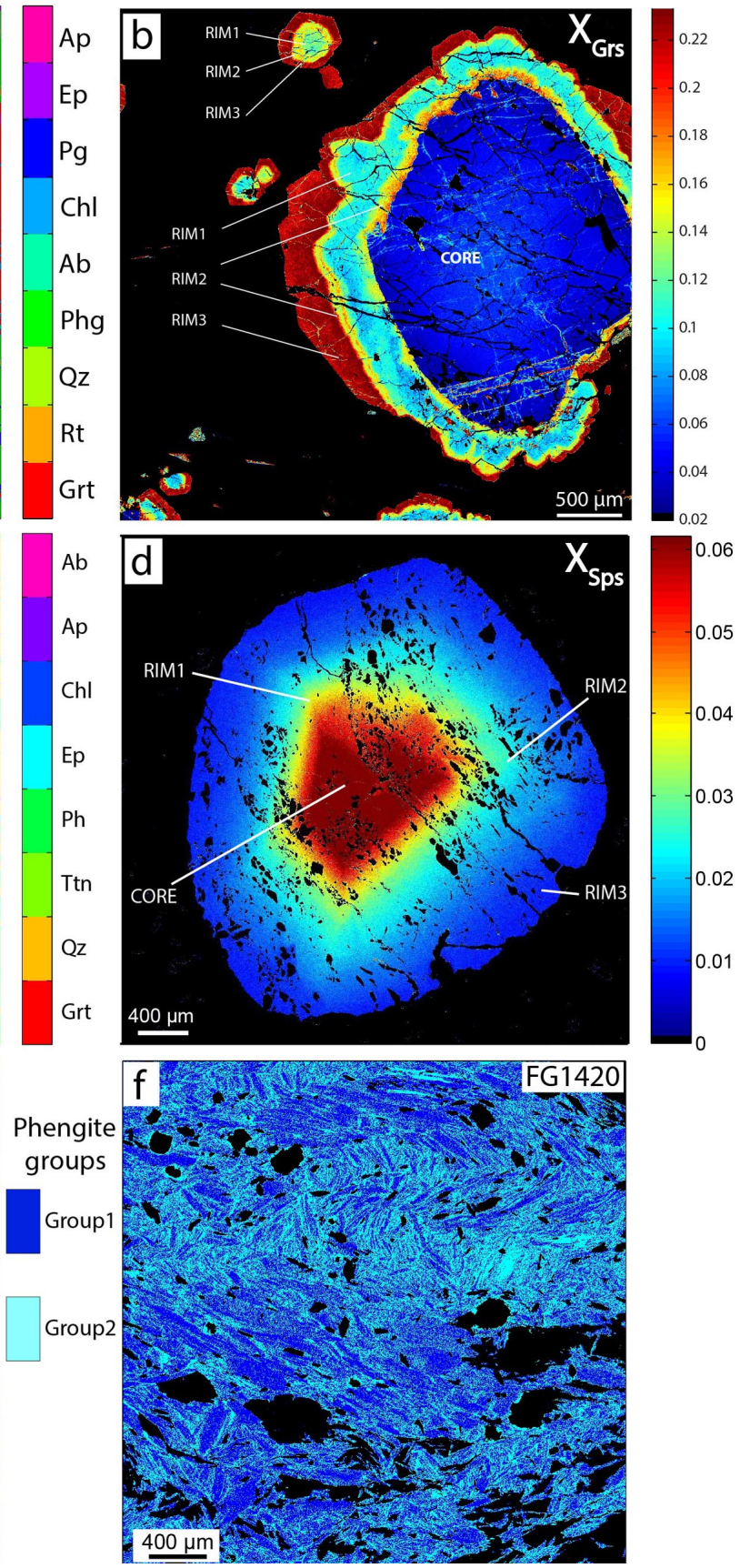

Figure 3. (a) Mineral phases in sample FG1249 (compare with Fig. 2c). (b) $X_{\mathrm{Grs}}$ map highlights the porphyroclastic cores showing fractures sealed by higher $X_{\mathrm{Grs}}$ garnet and three rims (further garnet endmember maps for the samples are available in Giuntoli et al., 2018). (c) Mineral phases in sample FG1420 (compare with Fig. 2g). (d) Garnet displaying concentric zoning related to a decrease in $X_{\text {Sps }}$. (Further garnet endmember maps for the samples are available in the Supplement S2). (e) Phengite groups in sample FG1249 (details in text). (f) Phengite groups in sample FG1420 (details in text). Note larger phengite flakes of Group2 localized in fold hinges.

sition. The latter is strongly affected by fractionation (i.e. the removal of refractive garnet, e.g. Evans, 2004; KonradSchmolke et al., 2008) and by resorption, which can shift the reactive bulk composition back toward the garnet composition (Lanari and Engi, 2017). The program GrtMod (Lanari et al., 2017) was specially developed to deal with samples in which garnet experienced a complex history involving several stages of growth, resorption, and/or pseudomorphic replacement. In essence, the program refines the reactive bulk composition used in free-energy minimization at each stage predicted if previously grown garnet was preserved or only partly dissolved. GrtMod uses an iterative approach that re- 
fines the $P-T$ conditions for successive garnet growth zones. For each inversion (i.e. a single growth stage), a solution was deemed acceptable if the least-squares residual value (the cost function $C_{0}$ used by Lanari et al., 2017) was $<0.05$, reflecting a sufficiently close match between the modelled and observed garnet compositions. In the IC samples, resorption and fractionation were constrained according to the volumetric proportion of each growth zone, as estimated from the thin section and the compositional maps. No resorption was permitted in the program for sample FG1420, as garnet textures in the compositional maps show no evidence of this process. To model the rim generation in the IC samples the "go fast mode" function (Lanari et al., 2017) was used, with an initial starting $P-T$ guess of $650^{\circ} \mathrm{C}$ and $1.6 \mathrm{GPa}$. The initial starting guess is an essential technicality used for reasons discussed by Lanari et al. (2017, Sects. 5.2.3 and 6.3); the specific purpose is to avoid local minima in optimization. This function searches a solution around the starting guess and follows the gradient in the objective function; there cannot be local minima at high pressure for this range of bulk rock composition (see Fig. 8 in Lanari et al., 2017). The MnO component was used in the thermodynamic computations of the relatively rich Mn garnet in sample FG1420. In sample FG1249, MnO was used to model the garnet core but was ignored in the models of the following rims because the concentration found in garnet is low $(<1 \mathrm{wt} \% \mathrm{MnO}$; Table1). In the remaining samples, $\mathrm{MnO}$ was ignored ( $<1 \mathrm{wt} \%)$, and the system considered in modelling was simplified to $\mathrm{SiO}_{2}$ $\mathrm{TiO}_{2}-\mathrm{Al}_{2} \mathrm{O}_{3}-\mathrm{FeO}-\mathrm{MgO}-\mathrm{CaO}-\mathrm{Na}_{2} \mathrm{O}-\mathrm{K}_{2} \mathrm{O}-\mathrm{H}_{2} \mathrm{O}$. The thermodynamic database used was the same as the one used to compute the isochemical phase diagrams (see below).

\subsubsection{Isochemical phase diagrams (pseudosections)}

Isochemical equilibrium phase diagrams were computed using the Gibbs free energy minimization algorithm Theriak-Domino (de Capitani and Brown, 1987; de Capitani and Petrakakis, 2010). The thermodynamic database of Berman (1988) with subsequent updates collected in JUN92.bs (distributed with Theriak-Domino 3 December 2012; Supplement S3) was used, together with the following solution models: Berman (1990) for garnet, Fuhrman and Lindsley (1988) for feldspar, Meyre et al. (1997) for omphacite, Keller et al. (2005) for white mica, and ideal mixing models for amphibole (Mäder and Berman, 1992; Mäder et al., 1994), epidote, and chlorite (Hunziker, 2003). All Gibbs free energy minimizations were carried out assuming an excess in pure $\mathrm{H}_{2} \mathrm{O}$ fluid. The amount of $\mathrm{H}_{2} \mathrm{O}$ component predicted at HP is in line with the measured loss of ignition (1.4$2.7 \mathrm{wt} \%$ ) in the present-day samples. Note that for the preAlpine HT computations no melt model was used. $\mathrm{Fe}^{3+}$ was ignored because of the lack of analytical data and suitable ferric endmembers in solid solution models.

\subsubsection{Chlorite and white mica multi-equilibrium}

To constrain the $P-T$ conditions of retrograde stages, multiequilibrium computations of the high-variance assemblages involving chlorite and white mica were carried out, using the standard state properties and solid solution models of Vidal et al. (2005, 2006) for chlorite, Dubacq et al. (2010) for phengite, and the program ChlMicaEqui (Lanari, 2012). The activity of $\mathrm{H}_{2} \mathrm{O}$ was set to unity. Three methods were successively employed:

1. Chlorite + quartz $+\mathrm{H}_{2} \mathrm{O}$ thermometry. The chlorite formation temperature and $\mathrm{XFe}^{3+}$ were estimated at a fixed pressure of $1 \mathrm{GPa}$ from the combination of four equilibria involving five chlorite endmembers, quartz, and $\mathrm{H}_{2} \mathrm{O}$ (Lanari et al., 2012; Vidal et al., 2016).

2. White mica + quartz $+\mathrm{H}_{2} \mathrm{O}$ barometry. A divariant $\mathrm{P}-$ $T$ equilibrium line was estimated for each white mica analysis (assuming $\mathrm{XFe}^{3+}=0$ ) from the convergence of three equilibria involving five phengite endmembers, quartz, and $\mathrm{H}_{2} \mathrm{O}$ (Dubacq et al., 2010).

3. Chlorite + white mica + quartz $+\mathrm{H}_{2} \mathrm{O}$ thermobarometry. $P$ and $T$ of formation for each chlorite and white mica couple, as well as their respective $\mathrm{XFe}^{3+}$ values, were estimated by minimizing the square root of the sum of $\left(\Delta G_{\text {reaction }}\right)^{2}$ for six equilibria (see Supplement S4).

For the sake of clarity, only 64 equilibria (excluding the pyrophyllite $1 \mathrm{H}_{2} \mathrm{O}$ endmember) are shown in the $P-T$ diagrams. The starting guess for $T$ and $P$ was taken from the result of chlorite + quartz $+\mathrm{H}_{2} \mathrm{O}$ thermometry and white mica + quartz $+\mathrm{H}_{2} \mathrm{O}$ barometry. This multiequilibrium approach relies on the assumption of local thermodynamic equilibrium between the selected chlorite and white mica at the $P-T$ conditions of convergence. Chlorite and white mica couples in which microtextural evidence suggested equilibrium, notably where sharp contacts were observed between these sheet silicates, were chosen.

\subsection{Bulk rock and reactive bulk composition}

For samples FG1324 and FG1420 the original bulk rock compositions obtained using XRF were used to compute isochemical phase diagrams. In samples FG1315, FG12157, FG1347, and FG1249, however, the unmodified bulk rock composition cannot be used for modelling because a significantly high volume fraction of garnet is present (5-10 vol \%), including a pre-Alpine core and Alpine rim generations. To compute equilibrium diagrams properly, the reactive bulk rock composition was approximated using the program GrtMod (see Sect. 5.1.2). Each isochemical phase diagram is thus valid for a single $P-T$ stage only. To select the reactive bulk composition of this specific stage, a link must be established between the particular garnet generation that formed 

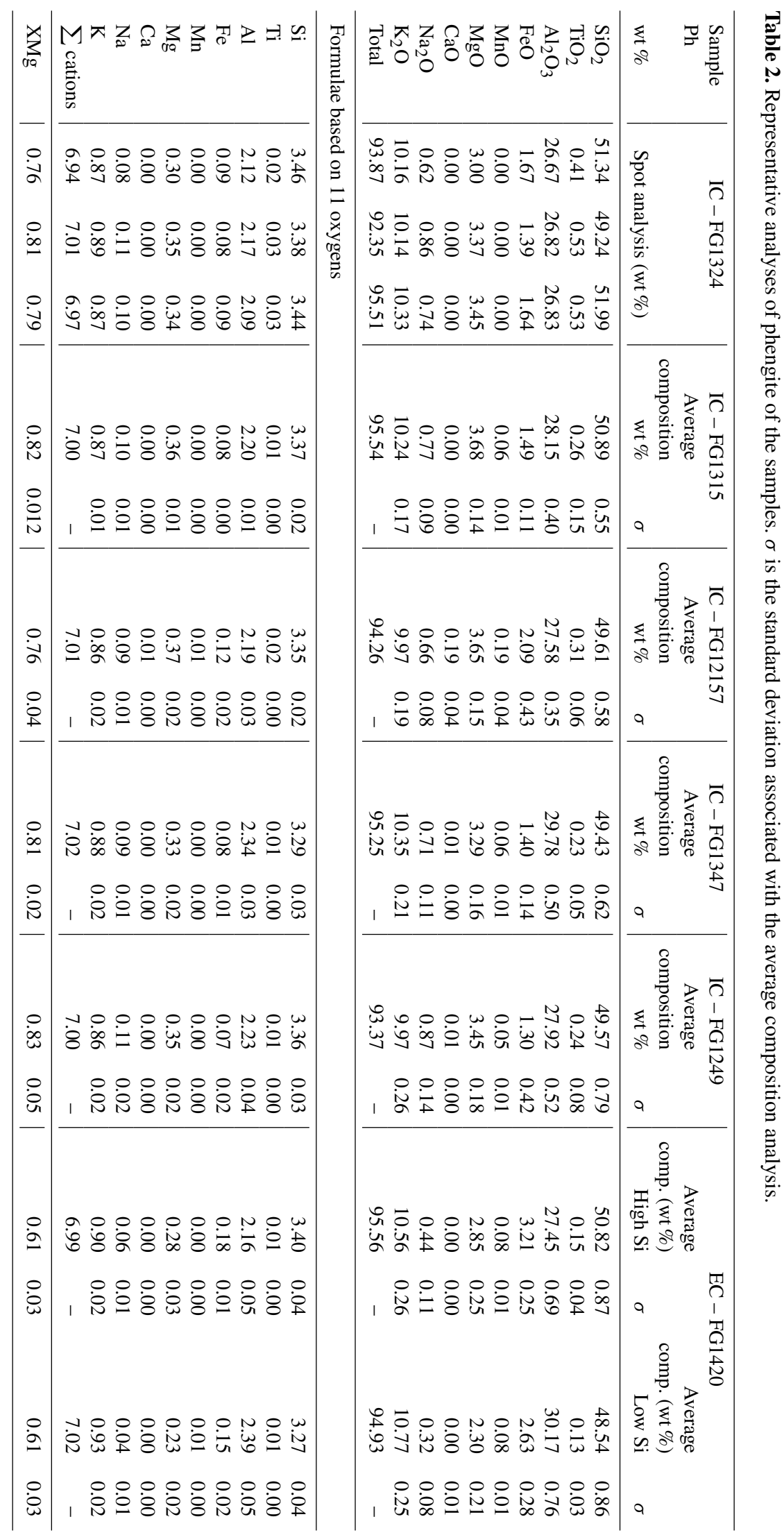
in equilibrium with the mineral phases present in the matrix and the mineral phases. We established this link using petrographic observations, including textural equilibrium criteria, compositional zoning (visible in compositional maps), and inclusion relationships. Specifically, we determined that the garnet growth zones that coexisted with the mineral matrix are as follows: garnet Rim3 for sample FG1315, Rim1 for sample FG12157, Rim3 for sample FG1347, and Rim2 for sample FG1249. The corresponding reactive bulk compositions used for the modelling are provided in the Supplement S5.

\subsection{Results: garnet thermobarometry and phase diagrams}

Figure 4 shows isochemical $P-T$ phase diagrams for each sample. The plots show the results of garnet thermobarometry (GrtMod), garnet isopleths $\left(X_{\mathrm{Grs}}, X_{\mathrm{Alm}}\right.$, and $X_{\mathrm{Prp}}$ in sample FG1324), and $X_{\mathrm{Mg}}$ and Si (apfu) isopleths for phengite. For sample FG1420, results of chlorite-white mica thermobarometry are also displayed. A summary of mineral compositional data for the main phases, the modelling method used, the XRF analyses of major elements of each sample, and details of the GrtMod results are available as Supplement S5$\mathrm{S} 7$ and S8, respectively. Each sample from the IC and EC is presented separately below.

\subsubsection{IC - FG1324 omphacite, garnet, glaucophane, and rutile mica schist}

Garnet isopleths (Alm, Grs, Prp) intersect in two areas of the $P-T$ diagram: at $1.65-1.75 \mathrm{GPa}$ and $600-650^{\circ} \mathrm{C}$ and at $1.9-$ $2 \mathrm{GPa}$ and $\sim 550^{\circ} \mathrm{C}$. Assuming equilibrium between garnet and phengite, these conditions can be further constrained by matching this result with the $\mathrm{Si}$ and $X_{\mathrm{Mg}}$ isopleths of phengite (measured values: $3.38-3.46$ and $0.76-0.81$, respectively). Phengite isopleths match the garnet composition at 1.65-1.75 GPa and 600-650 ${ }^{\circ} \mathrm{C}$ (Fig. 4a). Under these conditions, some discrepancies between observations and modelled assemblages are noted for this sample: paragonite instead of glaucophane is predicted to be stable in the model (probably because no solid solution model for sodic amphiboles is available in the thermodynamic database used). Also, $6 \mathrm{vol} \%$ biotite is predicted to be stable, whereas none was observed in thin section.

\subsubsection{IC - FG1315 garnet, epidote, and rutile quartz-mica schist}

The garnet core is found to be stable at $0.82 \mathrm{GPa}$ and $750{ }^{\circ} \mathrm{C}$, with a crystallization of $\sim 14$ vol \% (details available in Supplement S5 and S8). The first garnet rim is predicted stable at $\sim 1.5 \mathrm{GPa}$ and $650{ }^{\circ} \mathrm{C}$, with a resorption of $\sim 3.7 \mathrm{vol} \%$ garnet core and crystallization of $\sim 5.5 \mathrm{vol} \%$ Rim 1 . The second and third garnet rims are found to be stable at similar conditions: $1.9 \mathrm{GPa}$ and $650{ }^{\circ} \mathrm{C}$ and $1.8 \mathrm{GPa}$ (resorption of 2.3,
2.5 vol $\%$ core and Rim 1 , crystallization of 5.6 vol \% Rim 2 ) and at $670^{\circ} \mathrm{C}$ (resorption of $5,0.4$, and 3.1 vol \% core, Rim 1 , and Rim2, plus crystallization of $8.6 \mathrm{vol} \%$ Rim 3$) . P-T$ conditions of Rim 2 and 3 match with the intersection of Si (3.373.40) and $X_{\mathrm{Mg}}(0.80-0.82$; Fig. 4b) isopleths of phengite. The predicted assemblage conforms to the minerals observed in thin section (Supplement S1, S5).

\subsubsection{IC - FG12157 garnet, glaucophane, epidote, and rutile mica schist}

In this model, $\sim 7 \mathrm{vol} \%$ of garnet is modelled to be stable at $0.6 \mathrm{GPa}$ and $900{ }^{\circ} \mathrm{C}$; its composition corresponds to the garnet core. The first garnet rim is predicted to be stable at $1.6 \mathrm{GPa}-650^{\circ} \mathrm{C}$ (resorption of $\sim 1.4 \mathrm{vol} \%$ garnet core and crystallization of $\sim 10.8 \mathrm{vol} \% \mathrm{Rim} 1$ ), in agreement with the intersection of phengite isopleths for the observed values of Si (3.34-3.38) and $X_{\mathrm{Mg}}(0.76-0.82$; Fig. 4c). Crossite rims around glaucophane in this sample mark a decompression stage; this may correlate with the second rim in garnet, which is found to be stable at $1.4 \mathrm{GPa}$ and $650^{\circ} \mathrm{C}$ (resorption of $1.5 \mathrm{vol} \%$ core, $7.3 \mathrm{vol} \%$ Rim 1 , and crystallization of 10.6 vol \% Rim 2$)$. An amount of $4-6 \%$ biotite is predicted to be stable, but none is observed in thin section.

\subsubsection{IC - FG1347 chloritoid, garnet, and rutile mica schist}

The garnet core is modelled to be stable at $0.8 \mathrm{GPa}$ and $780^{\circ} \mathrm{C}$, with a crystallization of $\sim 17.7 \mathrm{vol} \%$. The three garnet rims show similar $P-T$ conditions: $1.9 \mathrm{GPa}, 590^{\circ} \mathrm{C}$ (resorption of $\sim 1.6 \mathrm{vol} \%$ garnet core and crystallization of $\sim 2.8$ vol \% Rim 1 ); $1.8 \mathrm{GPa}, 600^{\circ} \mathrm{C}$ (resorption of $3.2 \mathrm{vol} \%$ core, 1.4 vol \% Rim 1 , and crystallization of 5 vol \% Rim 2 ); 2.0 GPa , $600^{\circ} \mathrm{C}$ (crystallization of 2 vol \% Rim3). P-T estimates for the garnet rims are in perfect agreement with the intersection of phengite isopleths at $\mathrm{Si}$ apfu (3.29-3.33) and $X_{\mathrm{Mg}}(0.78-0.82$; Fig. 4d). The predicted assemblage matches the minerals observed, except that kyanite (3 vol \% predicted) was not detected in thin section.

\subsubsection{IC - FG1249 garnet, epidote, and rutile mica schist}

The garnet core is modelled to be stable at $0.6 \mathrm{GPa}$ and $730{ }^{\circ} \mathrm{C}$, with crystallization of $\sim 10 \mathrm{vol} \%$ garnet. Rim 1 is modelled to be stable at $0.6 \mathrm{GPa}$ and $620^{\circ} \mathrm{C}$ (resorption of $\sim 2$ vol $\%$ garnet core and crystallization of $\sim 2$ vol \% Rim 1 ). The second rim is related to the peak pressure recorded by this sample $\left(1.63 \mathrm{GPa}\right.$ and $615^{\circ} \mathrm{C}$ with resorption of 0.2 vol \% core and 0.05 vol \% Rim 1 , plus crystallization of 10 vol \% Rim2); conditions are in agreement with the Si apfu (3.35-3.4) and $X_{\mathrm{Mg}}(0.77-0.83$; Fig. 4e) compositions of phengite. The last rim recorded may mark the thermal peak at lower pressure $\left(1.56 \mathrm{GPa}, 660^{\circ} \mathrm{C}\right)$ with garnet resorption (6.9 vol \% Rim 2$)$ and growth $(8.6$ vol \% Rim 3$)$. 
(a)

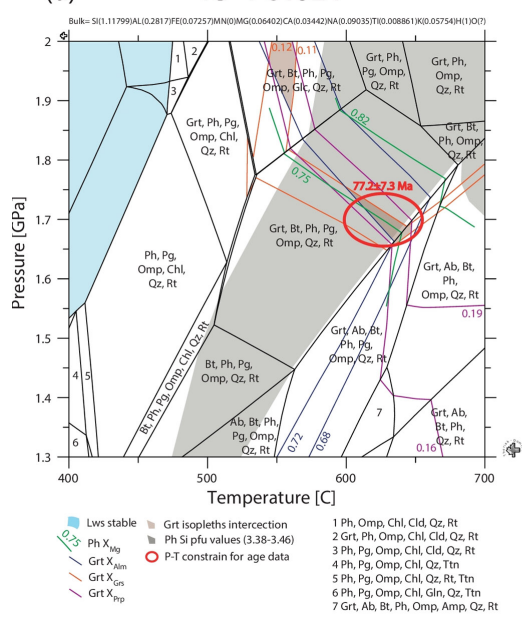

(b)
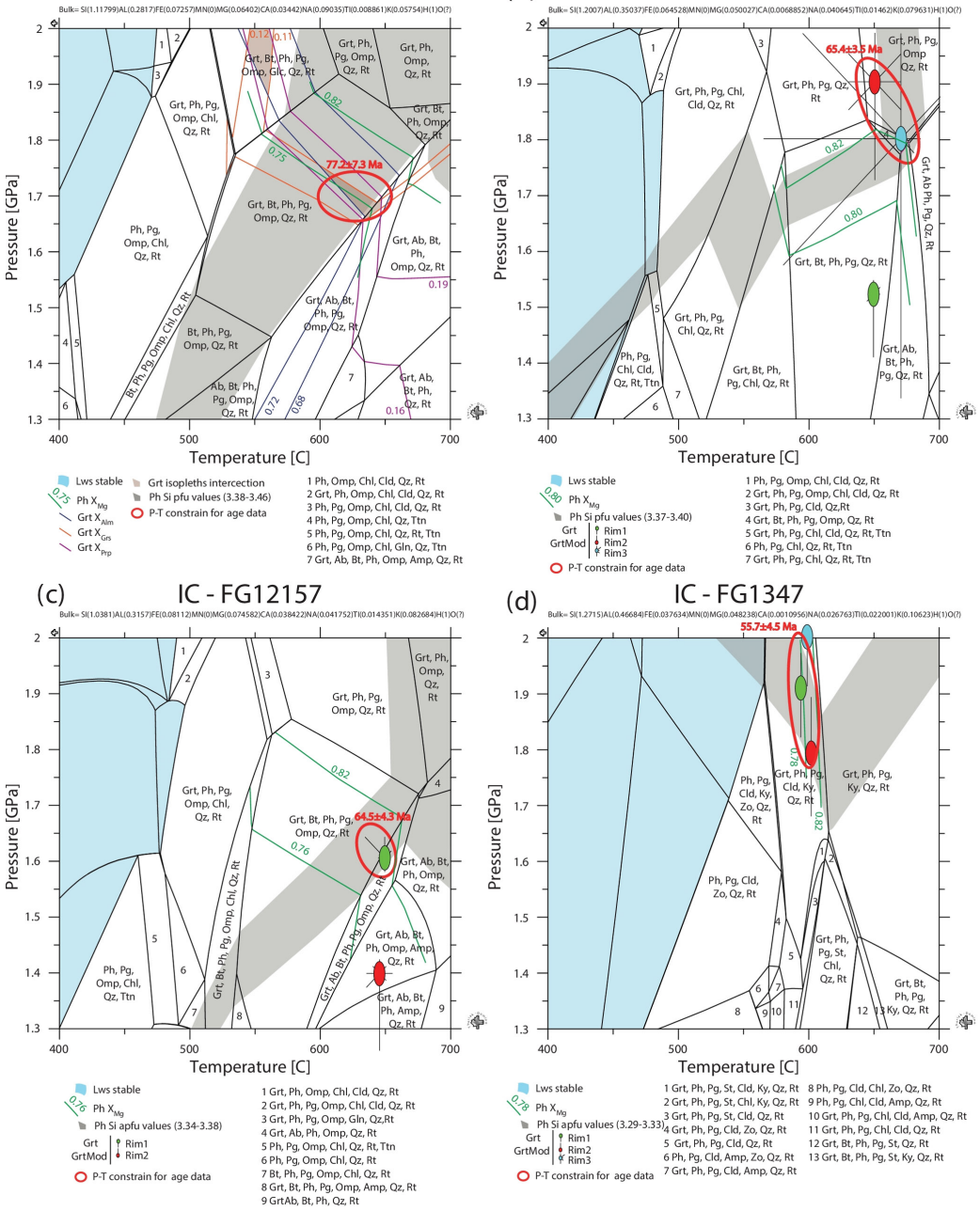

(e)

IC - FG1249

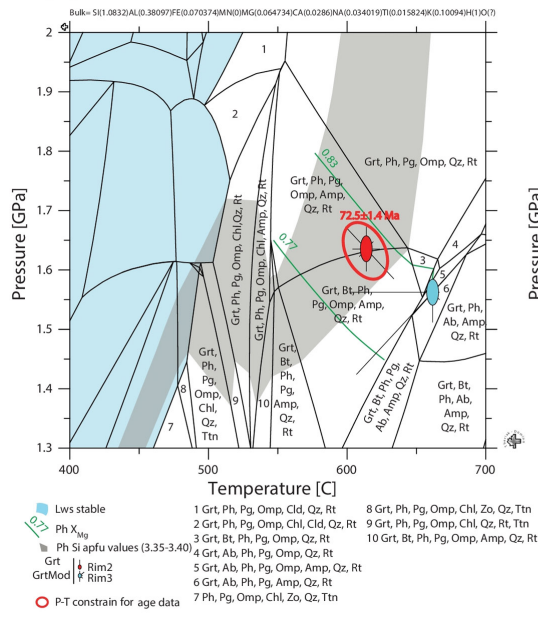

(d)

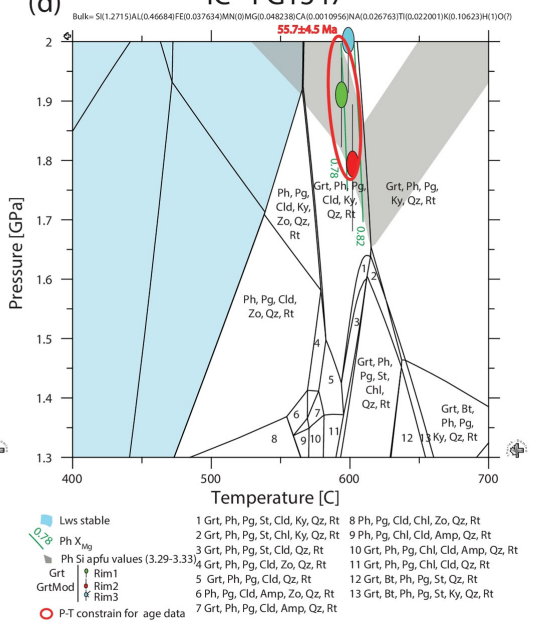

(f)
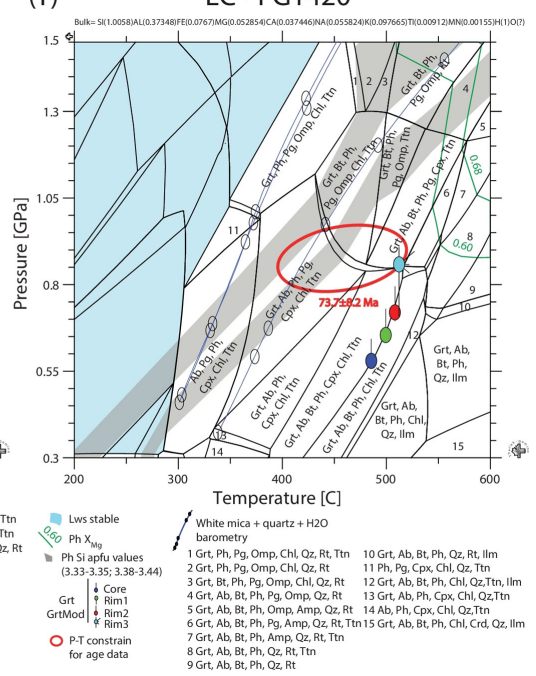

Figure 4. Equilibrium phase diagrams of the studied samples computed with Theriak-Domino, assuming a free $\mathrm{H}_{2} \mathrm{O}$ fluid, between 1.3 and $2 \mathrm{GPa}$ and between 400 and $700{ }^{\circ} \mathrm{C}$ for (a-e) and between 0.3 and $1.5 \mathrm{GPa}$ and between 200 and $600^{\circ} \mathrm{C}$ for (f). The error bars departing from filled ellipses show the $P-T$ uncertainty related to the analytical error of the garnet composition. 


\subsubsection{EC - FG1420 garnet orthogneiss}

The garnet core is found to be stable at $0.48 \mathrm{GPa}$ and $490^{\circ} \mathrm{C}$, Rim 1 at $0.67 \mathrm{GPa}$ and $500^{\circ} \mathrm{C}$, Rim2 at $0.73 \mathrm{GPa}$ and $510^{\circ} \mathrm{C}$, and $\operatorname{Rim} 3$ at $0.8 \mathrm{GPa}$ and $520^{\circ} \mathrm{C}$, with a total amount of 4.8 vol \% garnet.

Two phengite generations are present (Sect. 4.3; Fig. 3f): phengite describing the main foliation, with higher silica content, displays $\mathrm{Si}$ apfu and $X_{\mathrm{Mg}}$ isopleth intersection at $\sim 1.4 \mathrm{GPa}$ and $550^{\circ} \mathrm{C}$. These conditions are not substantiated by the mineral assemblage, which is predicted to contain omphacite and rutile, but neither phase was observed in thin section. Also, under these $P-T$ conditions further garnet growth is predicted, with a modal increase from 6.5 to $>7.5 \mathrm{vol} \%$, but no garnet is observed with a composition compatible with these $P-T$ conditions. We suspect that phengite grew at lower $P-T$ conditions, as the appropriate $\mathrm{Si}$ apfu values intersect the $P-T$ results derived from white mica + quartz $+\mathrm{H}_{2} \mathrm{O}$ barometry at $0.6-0.8 \mathrm{GPa}$ and $350-400{ }^{\circ} \mathrm{C}$ (Fig. 4f; more details in the next section).

The second generation of phengite, post-dating the main foliation, shows $\mathrm{Si}$ values for which the isopleths intersect with the results derived from white mica + quartz $+\mathrm{H}_{2} \mathrm{O}$ barometry at $0.55-0.75 \mathrm{GPa}$ and $300-350^{\circ} \mathrm{C}$.

\subsection{Results: multi-equilibrium thermobarometry}

\subsubsection{IC - FG1315 garnet, epidote, and rutile quartz-mica schist}

Chlorite in this sample is retrograde and records formation temperatures decreasing from $450{ }^{\circ} \mathrm{C}$ to $300^{\circ} \mathrm{C}$ (Fig. 5a). White mica + quartz $+\mathrm{H}_{2} \mathrm{O}$ barometry suggests pressures comprised between 1.5 and $0.4 \mathrm{GPa}$ for the temperature range of chlorite. Chlorite and white mica grains in textural equilibrium were used to constrain the equilibrium conditions at $0.8 \pm 0.2 \mathrm{GPa}$ and $340 \pm 50^{\circ} \mathrm{C}$ for the retrograde stage (Fig. 5b; Tables 3 and 4).

\subsubsection{IC - FG12157 garnet, glaucophane, epidote, and rutile mica schist}

Chlorite records formation temperatures decreasing from 430 to $310^{\circ} \mathrm{C}$ (Fig. $5 \mathrm{c}$ ). White mica + quartz $+\mathrm{H}_{2} \mathrm{O}$ barometry finds pressures between 0.02 and $1 \mathrm{GPa}$ for the temperature range shown by chlorite. Chlorite and white mica grains in textural equilibrium are used to approximate equilibrium conditions at $0.54 \pm 0.2 \mathrm{GPa}$ and $394 \pm 50^{\circ} \mathrm{C}$ for the retrograde stage (Fig. 5d).

\subsubsection{IC - FG1347 chloritoid, garnet, and rutile mica schist}

Chlorite registers temperatures from 370 to $250^{\circ} \mathrm{C}$ (Fig. 5e). White mica + quartz $+\mathrm{H}_{2} \mathrm{O}$ barometry indicates pressures between 0.02 and $1 \mathrm{GPa}$ for the temperature range of chlo- rite. Chlorite and white mica grains record $0.78 \pm 0.2 \mathrm{GPa}$ and $341 \pm 50^{\circ} \mathrm{C}$ for the retrograde stage (Fig. 5f).

\subsubsection{EC - FG1420 garnet orthogneiss}

The chlorite and white mica multi-equilibrium technique was used to constrain the equilibrium conditions of three successive stages of retrogression using couples linked to different microstructural positions that developed after the main foliation. These show equilibrium conditions at $0.87 \pm 0.2 \mathrm{GPa}$ and $354 \pm 50{ }^{\circ} \mathrm{C}$ in fold hinges, in pressure shadows at $0.6 \pm 0.2 \mathrm{GPa}$ and $331 \pm 50^{\circ} \mathrm{C}$, and in static overgrowths over the main foliation at $0.42 \pm 0.2 \mathrm{GPa}$ and $231 \pm 50^{\circ} \mathrm{C}$ (Fig. 6).

\section{Texture and geochronology of allanite and zircon}

\subsection{Methods}

\subsubsection{Allanite geochronology}

Allanite was first investigated in detail in thin section (see Sect. 7), but for more efficient dating purposes, allanite grains were separated using high-voltage pulsed-power disintegration (Selfrag device at University of Bern; e.g. Rudashevsky et al., 1995) followed by magnetic separation and heavy liquids, hand-picked, mounted in acryl or epoxy, and polished to equatorial section. The grains were imaged using SEM (BSE) to document the internal texture and compositional zoning. Allanite dating was performed using a LAICP-MS GeoLas Pro $193 \mathrm{~nm}$ ArF excimer laser coupled to an Elan Dynamic Reaction Cell (DRC-e) ICP-MS (Institute of Geological Sciences, University of Bern). The analytical procedure followed is described in detail in Burn et al. (2017). In particular, pre-ablation was performed for four to five pulses using an energy density of $2.5 \mathrm{~J} \mathrm{~cm}^{-2}$, a repetition rate of $1 \mathrm{~Hz}$, and spot sizes of 40 and $32 \mu \mathrm{m}$. Ablation was performed using an energy density of $2.5 \mathrm{~J} \mathrm{~cm}^{-2}$, a repetition rate of $9 \mathrm{~Hz}$, and spot sizes of 32 and $24 \mu \mathrm{m} . \mathrm{He}\left(1 \mathrm{~L} \mathrm{~min}^{-1}\right)$ and $\mathrm{H}_{2}\left(0.08 \mathrm{~L} \mathrm{~min}^{-1}\right)$ were used as aerosol transport. The instrument setting was optimized for heavy masses, and oxide production $\left(\mathrm{ThO}^{+} / \mathrm{Th}^{+}\right)$was decreased to be lower than $0.5 \%$. NIST SRM 610 measurements were performed for quantification of $U$ and Th concentrations. Plešovice (Sláma et al., 2008) zircon was used as the primary standard. Cima d'Asta Pluton (CAP) allanite was used as a secondary standard. The acquisition series were approximately $1 \mathrm{~h}$ to minimize instrumental drift, including between 8 and 12 unknown analyses bracketed by eight analyses of the primary standard Plešovice used for $\mathrm{U}-\mathrm{Th}-\mathrm{Pb}$ ratio calibration, SRM 610 for trace element calibration, and three analyses of the secondary reference material $\mathrm{CAP}^{\mathrm{b}}$. Data reduction was performed with the in-house program Trinity (Burn et al., 2017). Data for the secondary standards are reported in Supplement S9. Uncertainties given in the text and figures do not 
(a)

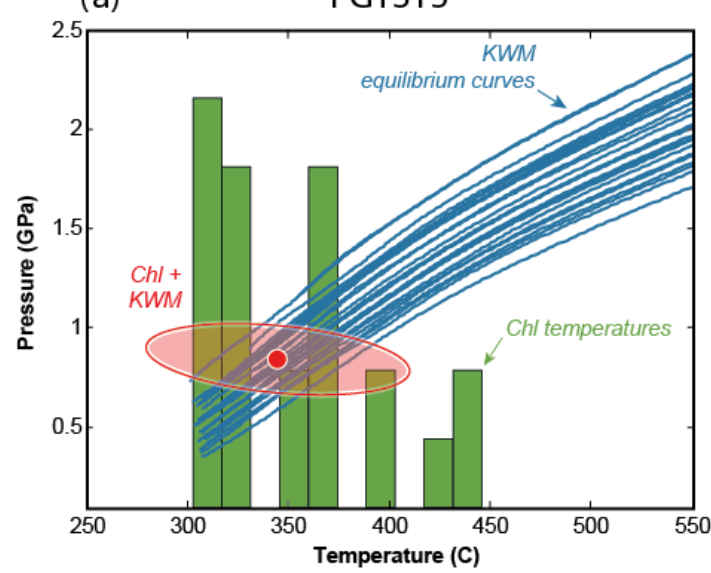

(c)
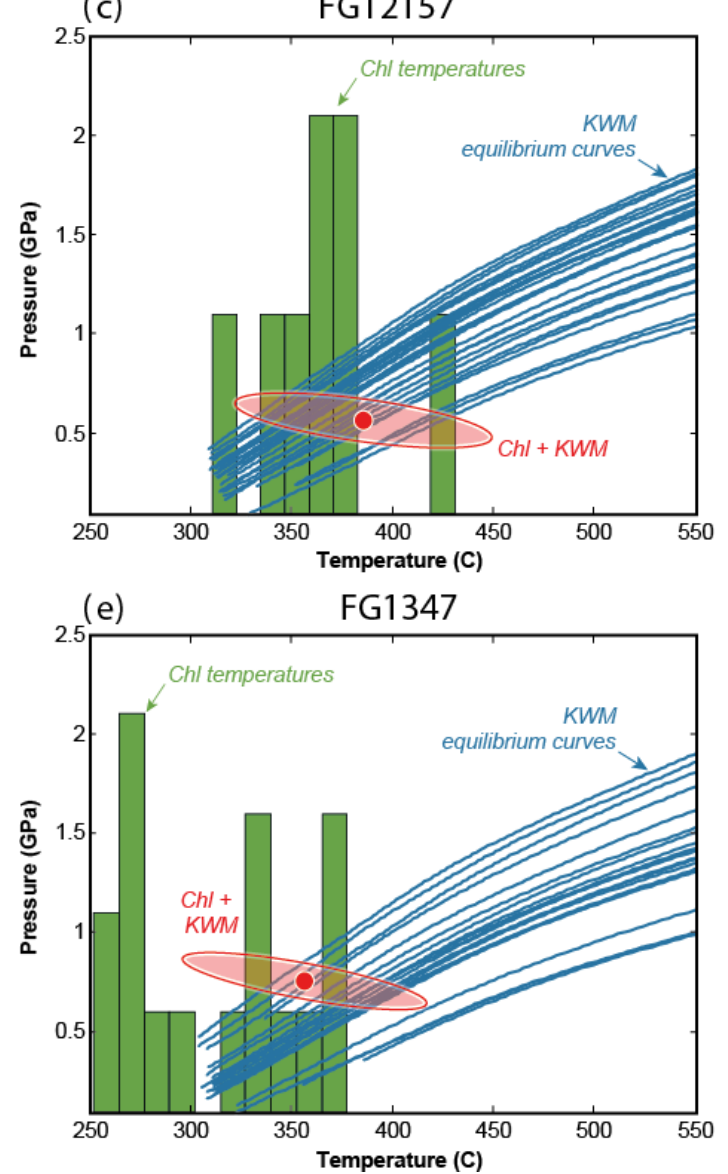

(b)

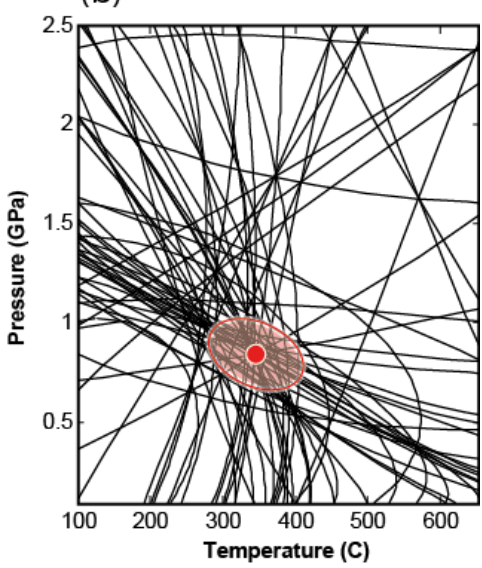

(d)
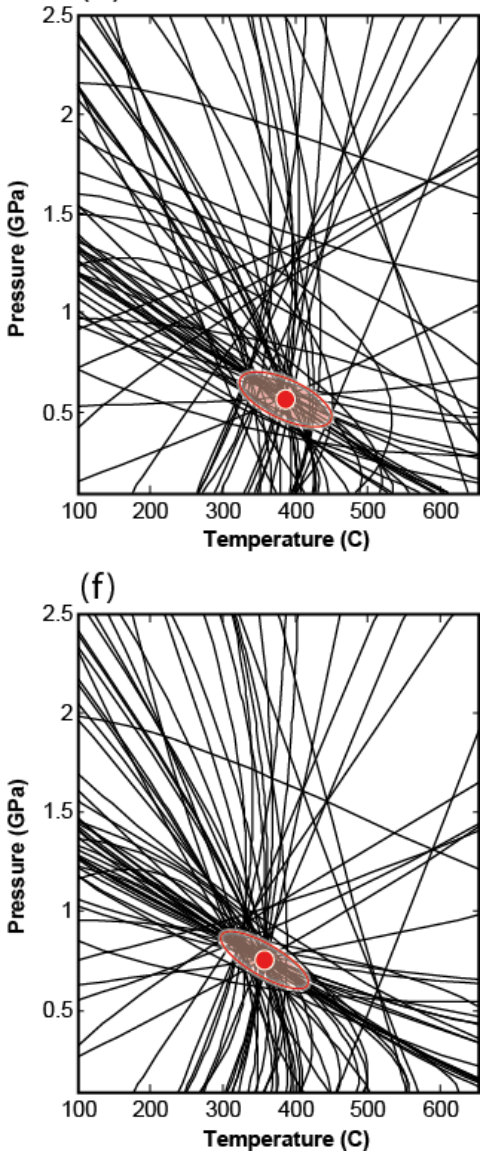

Figure 5. Multi-equilibrium thermobarometry results for the IC samples. Panels (a, c) and (e) show the intersection of the results deriving from chlorite + quartz $+\mathrm{H}_{2} \mathrm{O}$ thermometry with white mica + quartz $+\mathrm{H}_{2} \mathrm{O}$ barometry. Panels (b, d) and (f) show results of chlorite + white mica + quartz $+\mathrm{H}_{2} \mathrm{O}$ thermobarometry.

include the systematic uncertainties as defined by Horstwood et al. (2016) because the value appears to be quite variable depending on the reference material used (see Burn et al., 2017). In theory, the total uncertainties may be slightly underestimated, whereas the low mean square weighted devia- tion (MSWD) values rather suggest that the total uncertainties are slightly overestimated. 
Table 3. Representative analyses of chlorite used in the multi-equilibrium calculations

\begin{tabular}{|c|c|c|c|c|c|c|c|c|c|}
\hline \multirow{2}{*}{$\begin{array}{l}\text { Sample } \\
\text { Chl }\end{array}$} & \multicolumn{2}{|c|}{ IC - FG1315 } & \multicolumn{2}{|c|}{ IC - FG12157 } & \multicolumn{2}{|c|}{ IC - FG1347 } & \multicolumn{3}{|c|}{ EC - FG1420 } \\
\hline & $\begin{array}{r}\text { Chl- } \\
35093\end{array}$ & $\begin{array}{r}\text { Chl- } \\
35092\end{array}$ & $\begin{array}{r}\text { Chl- } \\
204162\end{array}$ & $\begin{array}{r}\text { Chl- } \\
204794\end{array}$ & $\begin{array}{r}\text { Chl- } \\
214479\end{array}$ & $\begin{array}{r}\text { Chl- } \\
215870\end{array}$ & $\begin{array}{r}\text { Grp1 } \\
\text { Chl- } \\
910650\end{array}$ & $\begin{array}{r}\text { Grp2 } \\
\text { Chl- } \\
547806\end{array}$ & $\begin{array}{r}\text { Grp3 } \\
\text { Chl- } \\
881538\end{array}$ \\
\hline $\mathrm{SiO}_{2}$ & 25.64 & 26.22 & 25.81 & 25.91 & 24.91 & 25.62 & 25.11 & 25.91 & 25.45 \\
\hline $\mathrm{Al}_{2} \mathrm{O}_{3}$ & 19.62 & 19.71 & 20.64 & 20.1 & 21.7 & 20.97 & 20.09 & 21.63 & 20.34 \\
\hline $\mathrm{FeO}$ & 26.29 & 26.68 & 24.53 & 27.34 & 24.96 & 26.45 & 26.87 & 28.98 & 25.53 \\
\hline $\mathrm{MnO}$ & 0.05 & 0.05 & 0.21 & 0.33 & 0.11 & 0.19 & 0.28 & 0.31 & 0.27 \\
\hline $\mathrm{MgO}$ & 15.32 & 15.82 & 15.87 & 14.32 & 13.51 & 13.49 & 13.01 & 12.61 & 12.61 \\
\hline $\mathrm{CaO}$ & 0.05 & 0.06 & 0.03 & 0.03 & 0.13 & 0.09 & 0.08 & 0.09 & 0.17 \\
\hline $\mathrm{Na}_{2} \mathrm{O}$ & 0.05 & 0.03 & 0.04 & 0.03 & 0 & 0.03 & 0.02 & 0.03 & 0.03 \\
\hline $\mathrm{K}_{2} \mathrm{O}$ & 0.07 & 0.06 & 0.02 & 0.03 & 0.15 & 0.22 & 0.03 & 0.03 & 0.06 \\
\hline Total & 87.09 & 88.63 & 87.15 & 88.09 & 85.47 & 87.06 & 85.49 & 89.59 & 84.46 \\
\hline \multicolumn{10}{|c|}{ Atom site distribution (14 anhydrous-oxygen basis including $\mathrm{Fe}^{3+}$ ) } \\
\hline $\mathrm{Si}(\mathrm{T} 1+\mathrm{T} 2)$ & 2.68 & 2.71 & 2.70 & 2.69 & 2.65 & 2.72 & 2.73 & 2.70 & 2.78 \\
\hline $\mathrm{Al}(\mathrm{T} 2)$ & 1.32 & 1.29 & 1.30 & 1.31 & 1.34 & 1.28 & 1.27 & 1.30 & 1.22 \\
\hline $\mathrm{Al}(\mathrm{M} 1)$ & 0.32 & 0.29 & 0.30 & 0.31 & 0.34 & 0.28 & 0.27 & 0.30 & 0.22 \\
\hline $\operatorname{Mg}(\mathrm{M} 1)$ & 0.28 & 0.33 & 0.35 & 0.27 & 0.24 & 0.31 & 0.30 & 0.27 & 0.30 \\
\hline $\mathrm{Fe}^{2+}(\mathrm{M} 1)$ & 0.20 & 0.26 & 0.27 & 0.21 & 0.21 & 0.32 & 0.33 & 0.32 & 0.32 \\
\hline $\mathrm{V}(\mathrm{M} 1)$ & 0.20 & 0.12 & 0.09 & 0.21 & 0.21 & 0.10 & 0.10 & 0.11 & 0.16 \\
\hline $\mathrm{Mg}(\mathrm{M} 2+\mathrm{M} 3)$ & 2.10 & 2.10 & 2.13 & 1.95 & 1.90 & 1.83 & 1.80 & 1.69 & 1.75 \\
\hline $\mathrm{Fe}(\mathrm{M} 2+\mathrm{M} 3)$ & 1.46 & 1.61 & 1.64 & 1.57 & 1.62 & 1.87 & 1.94 & 2.03 & 1.85 \\
\hline $\mathrm{Al}(\mathrm{M} 2+\mathrm{M} 3)$ & 0.41 & 0.26 & 0.19 & 0.44 & 0.43 & 0.24 & 0.21 & 0.24 & 0.34 \\
\hline $\mathrm{Al}(\mathrm{M} 4)$ & 0.36 & 0.56 & 0.76 & 0.41 & 0.60 & 0.84 & 0.83 & 0.82 & 0.84 \\
\hline $\mathrm{XMg}$ & 0.59 & 0.57 & 0.56 & 0.55 & 0.54 & 0.49 & 0.48 & 0.45 & 0.49 \\
\hline $\mathrm{Fe}^{3+}(\mathrm{M} 4)$ & 0.64 & 0.44 & 0.24 & 0.59 & 0.40 & 0.16 & 0.17 & 0.18 & 0.16 \\
\hline
\end{tabular}

(a) FG1420 - Grp1

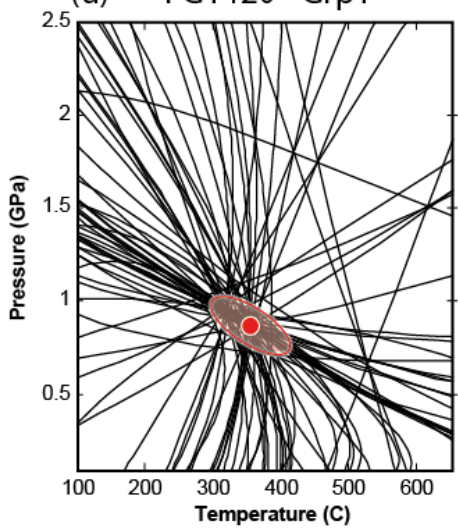

(b) FG1420 - Grp2

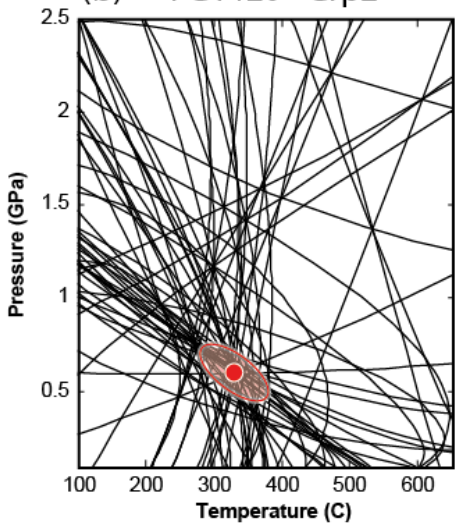

(c) FG1420 - Grp3

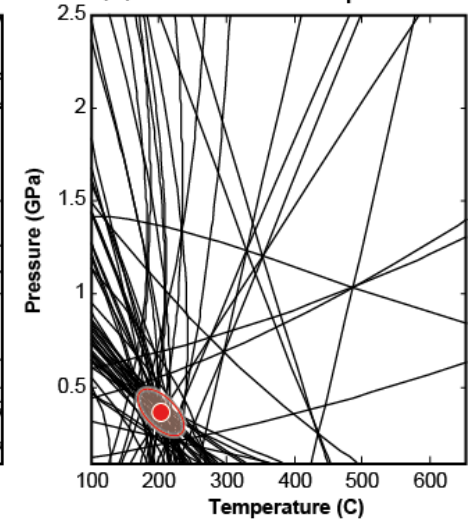

Figure 6. Chlorite + white mica + quartz $+\mathrm{H}_{2} \mathrm{O}$ thermobarometry results for the EC sample.

\subsubsection{Zircon geochronology}

Individual grains of zircon were separated as described for allanite and investigated using SEM, using CL imaging to document their internal textures. Zircon dates were obtained using the same LA-ICP-MS instrument, following the measurement procedures described by Kunz et al. (2017). Ablation was conducted with an energy density of $2.5 \mathrm{~J} \mathrm{~cm}^{-2}$, a repetition rate of $9 \mathrm{~Hz}$, and spot sizes of 32 or $16 \mu \mathrm{m}$. Samples were bracketed by the zircon standard GJ-1 (Jackson et al., 2004) and NIST SRM 612 measurements for quantification of $\mathrm{U}$, Th, and other trace element concentrations, using ${ }^{29} \mathrm{Si}$ as an internal standard. For accuracy and long-term reproducibility, Plešovice was measured as the secondary zircon standard giving a ${ }^{206} \mathrm{~Pb} /{ }^{238} \mathrm{U}$ weighted mean age of $339.2 \pm 1.6 \mathrm{Ma}(n=34$; error $2 \sigma)$. Acquisition series took 
Table 4. Representative analyses of white mica used in the multi-equilibrium calculations

\begin{tabular}{|c|c|c|c|c|c|c|c|c|c|}
\hline \multirow{3}{*}{$\begin{array}{l}\text { Sample } \\
\mathrm{Wm}\end{array}$} & \multirow{2}{*}{\multicolumn{2}{|c|}{ IC - FG1315 }} & \multirow{2}{*}{\multicolumn{2}{|c|}{ IC - FG12157 }} & \multirow{2}{*}{\multicolumn{2}{|c|}{ IC - FG1347 }} & \multicolumn{3}{|c|}{$\mathrm{EC}-\mathrm{FG} 1420$} \\
\hline & & & & & & & Grp1 & Grp2 & Grp3 \\
\hline & $\begin{array}{r}\text { Wm- } \\
20328\end{array}$ & $\begin{array}{l}\text { Wm- } \\
20330\end{array}$ & $\begin{array}{r}\text { Wm- } \\
232431\end{array}$ & $\begin{array}{r}\text { Wm- } \\
231796\end{array}$ & $\begin{array}{r}\text { Wm- } \\
245987\end{array}$ & $\begin{array}{r}\text { Wm- } \\
245295\end{array}$ & $\begin{array}{r}\text { Wm- } \\
883652\end{array}$ & $\begin{array}{r}\text { Wm- } \\
558805\end{array}$ & $\begin{array}{r}\text { Wm- } \\
851517\end{array}$ \\
\hline $\mathrm{SiO}_{2}$ & 48.06 & 48.48 & 48.23 & 47.06 & 49.56 & 49.29 & 50.45 & 50.56 & 49.03 \\
\hline $\mathrm{Al}_{2} \mathrm{O}_{3}$ & 28.22 & 28.12 & 30.09 & 29.98 & 31.01 & 29.62 & 28.75 & 28.95 & 27.97 \\
\hline $\mathrm{FeO}$ & 1.86 & 1.77 & 2.5 & 2.32 & 2.64 & 2.83 & 2.48 & 3.13 & 3.28 \\
\hline $\mathrm{MnO}$ & 0.04 & 0.06 & 0.27 & 0.2 & 0.06 & 0.06 & 0.09 & 0.1 & 0.13 \\
\hline $\mathrm{MgO}$ & 3.15 & 3.03 & 2.67 & 2.71 & 2.89 & 2.98 & 2.27 & 2.52 & 2.44 \\
\hline $\mathrm{CaO}$ & 0.02 & 0.03 & 0.27 & 0.23 & 0.01 & 0.01 & 0 & 0 & 0 \\
\hline $\mathrm{Na}_{2} \mathrm{O}$ & 0.52 & 0.58 & 0.47 & 0.6 & 0.49 & 0.58 & 0.37 & 0.28 & 0.26 \\
\hline $\mathrm{K}_{2} \mathrm{O}$ & 9.49 & 9.36 & 10.04 & 10.17 & 10.14 & 10.5 & 10.17 & 11.01 & 11.04 \\
\hline Total & 91.36 & 91.43 & 94.54 & 93.27 & 96.8 & 95.87 & 94.58 & 96.55 & 94.15 \\
\hline \multicolumn{10}{|c|}{ Atom site distribution (11 anhydrous-oxygen basis including $\mathrm{Fe}^{3+}$ ) } \\
\hline $\mathrm{Si}(\mathrm{T} 1+\mathrm{T} 2)$ & 3.32 & 3.35 & 3.24 & 3.22 & 3.25 & 3.28 & 3.37 & 3.34 & 3.33 \\
\hline $\mathrm{Al}(\mathrm{T} 2)$ & 0.68 & 0.65 & 0.76 & 0.78 & 0.75 & 0.72 & 0.63 & 0.66 & 0.67 \\
\hline V (M1) & 0.94 & 0.95 & 0.98 & 0.97 & 0.94 & 0.95 & 1.00 & 0.99 & 1.00 \\
\hline $\mathrm{Mg}(\mathrm{M} 1)$ & 0.04 & 0.04 & 0.03 & 0.03 & 0.04 & 0.03 & 0.00 & 0.01 & 0.01 \\
\hline $\mathrm{Fe}^{2+}(\mathrm{M} 1)$ & 0.01 & 0.01 & 0.01 & 0.01 & 0.02 & 0.02 & 0.00 & 0.01 & 0.00 \\
\hline $\mathrm{Al}(\mathrm{M} 2+\mathrm{M} 3)$ & 1.63 & 1.64 & 1.63 & 1.64 & 1.64 & 1.60 & 1.64 & 1.60 & 1.58 \\
\hline $\mathrm{Mg}(\mathrm{M} 2+\mathrm{M} 3)$ & 0.28 & 0.27 & 0.24 & 0.25 & 0.24 & 0.26 & 0.22 & 0.24 & 0.24 \\
\hline $\mathrm{Fe}(\mathrm{M} 2+\mathrm{M} 3)$ & 0.09 & 0.09 & 0.11 & 0.12 & 0.12 & 0.14 & 0.12 & 0.14 & 0.14 \\
\hline $\mathrm{XMg}$ & 0.75 & 0.75 & 0.68 & 0.68 & 0.66 & 0.65 & 0.65 & 0.64 & 0.64 \\
\hline $\mathrm{K}(\mathrm{A})$ & 0.84 & 0.82 & 0.86 & 0.89 & 0.85 & 0.89 & 0.87 & 0.93 & 0.96 \\
\hline $\mathrm{Na}(\mathrm{A})$ & 0.07 & 0.08 & 0.06 & 0.08 & 0.06 & 0.07 & 0.05 & 0.04 & 0.03 \\
\hline$V(A)$ & 0.09 & 0.10 & 0.06 & 0.02 & 0.09 & 0.03 & 0.08 & 0.04 & 0.01 \\
\hline
\end{tabular}

approximately $1 \mathrm{~h}$ to minimize instrumental drift and were composed of the following: two SRM glasses, three GJ-1 zircon, six to eight zircon unknowns, three to four Plešovice zircon, six to eight zircon unknowns, three GJ-1 zircon, and two SRM glasses. Data reduction was performed with Iolite 2.5 (Paton et al., 2010, 2011) with data reduction scheme "Visual age" (Petrus and Kamber, 2012). All dates reported in this study are concordant within their uncertainty; no common $\mathrm{Pb}$ correction was applied.

\subsection{Results: allanite textures and their microstructural relations}

In the samples of the IC, allanite prisms are elongate in the eclogite foliation, showing mutual intergrowth relations with phengite, garnet, paragonite, and rutile, which define this main foliation (Fig. 7a). In samples FG1324, FG1315, and FG1347 allanite crystals are characterized by one main growth zone. Some thin $(<20-30 \mu \mathrm{m})$ allanite rims as well as epidote or clinozoisite rims that appear dark in BSE photos are observed (Fig. 7a, b); where present, these mark a retrograde greenschist overprint. In samples FG12157 and FG1249, BSE pictures show one or more allanite rims characterized by lower brightness (Fig. 7b, c). These rims may reflect minor retrograde stages that weakly altered the eclog- ite facies assemblage as well. Again, a peripheral epidote rim is present. Monazite is occasionally observed as a relic in allanite cores in samples FG1324, FG1315, FG1347, and FG1249. Monazite shows lobate edges and is surrounded by symplectites (micrometres in size) of allanite and apatite or by discrete crystals of apatite and allanite (Fig. 7d). These features suggest prograde growth of allanite and apatite at the expense of monazite, a common allanite-forming reaction (e.g. Janots et al., 2008).

Various mineral inclusions are found in allanite grains, as summarized in Table 5. In detail, allanite in sample FG1324 shows intergrowths with garnet (Fig. 7e), suggesting synchronous growth of the two minerals. Phengite inclusions analysed in allanite show the same chemical composition as those marking the main foliation (representative mineral analyses are available in Supplement S5). Based on these features and the alignment in the foliation, allanite is interpreted to have grown syn-kinematically in the foliation and at the same time as garnet. In sample FG1315 allanite includes phengite, paragonite, and garnet (Fig. 7a, f); the latter is similar in composition to the Alpine HP rims and atoll garnet. Phengite inclusions have the same composition as phengite marking the main foliation and as phengite included in atoll garnet. Due to the relationships of these mutual inclusions in this sample, allanite growth again appears to be related to 


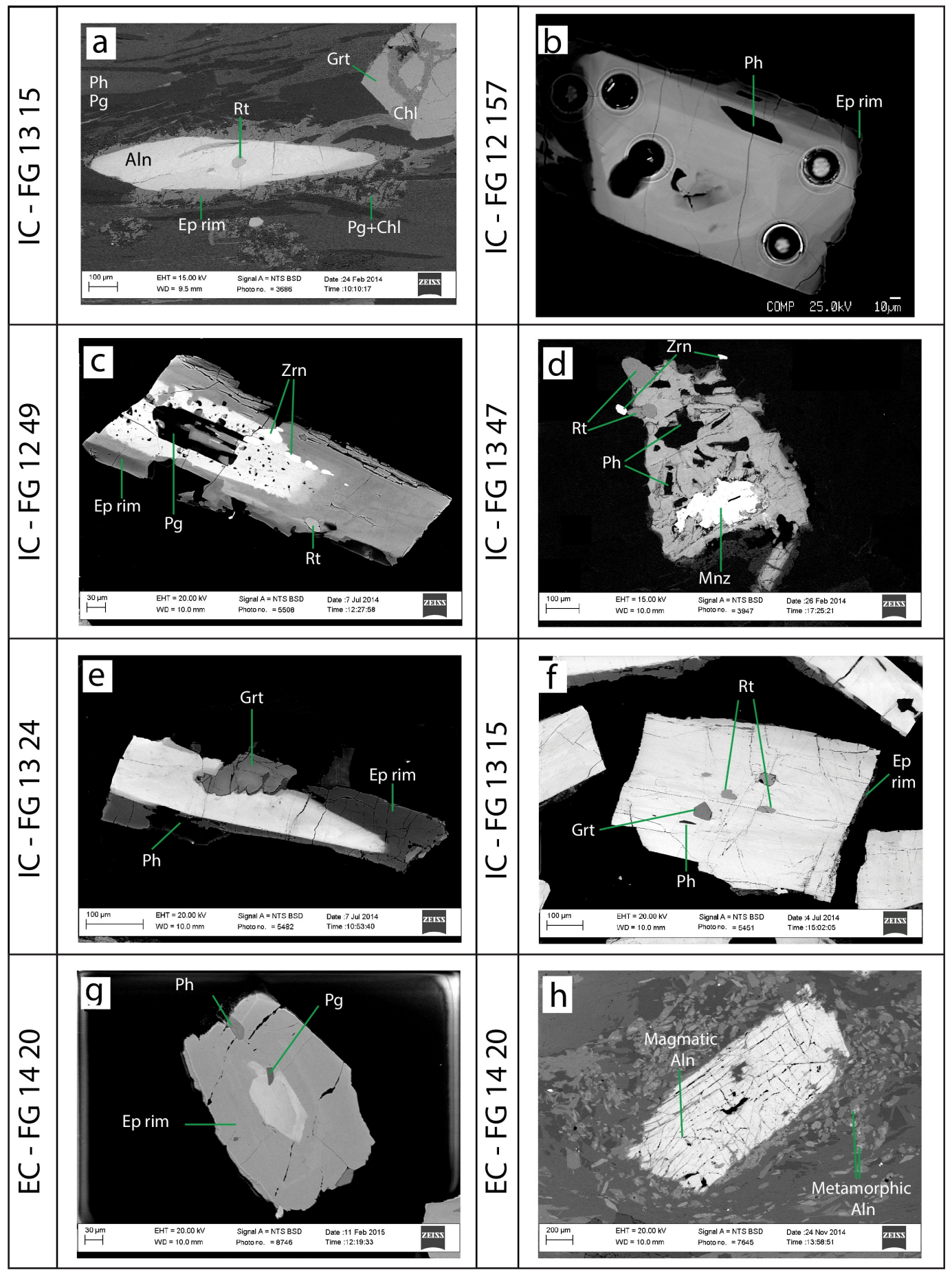

Figure 7. Backscattered electron photos illustrating some of the allanite crystals in the studied samples (a-h thin sections; b-g grain mounts). (a) Allanite grain elongate in the eclogite foliation with phengite and paragonite. It is rimmed by epidote and a simplectite of paragonite and chlorite. (b) Allanite displaying several growth zones and a dark outermost rim of epidote. Note the phengite inclusion and laser ablation pits $(32 \mu \mathrm{m})$. (c) Allanite displaying several growth zones, the innermost of which are intergrown with paragonite. The tiny dark inclusions are phengite and paragonite with fine grain size. (d) Monazite with lobate edges preserved at the core of an allanite grain. (e) Allanite intergrown with garnet and wrapped by a darker epidote rim. (f) Allanite including garnet, rutile, and phengite. (g) Allanite preserved at the core of epidote. Inclusions of paragonite and phengite are present at the boundary allanite-epidote rim. (h) Magmatic allanite with epidote crystals as satellites; some of the latter display cores of metamorphic allanite. 
Table 5. Constraints linking age data to pressure and temperature based on mineral inclusions in allanite; uncertainties of age data are $2 \sigma$. Allanite age data based on Tera-Wasserburg intercepts. Zircon ${ }^{206} \mathrm{~Pb} /{ }^{238} \mathrm{U}$ dates are given as the minimum and maximum range of individual analysis. Groups are discussed in Sect. 7.

\begin{tabular}{|c|c|c|c|c|c|c|c|c|}
\hline & Sample & Group & Age $\operatorname{Aln}(2 \sigma)$ & Age Zrn & $P$ & $T$ & Constraints & Name \\
\hline \multirow{5}{*}{ 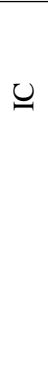 } & FG1324 & 1 & $77.2 \pm 7.3$ & $77-63$ & $1.65-1.75 \mathrm{GPa}$ & $600-650$ & Inclusion of $\mathrm{Ph}, \mathrm{Grt}$ & $\begin{array}{l}\text { Omp, Grt, Gln, and Rt } \\
\text { mica schist }\end{array}$ \\
\hline & FG1315 & 2 & $65.4 \pm 3.5$ & $68-58$ & $1.75-1.9 \mathrm{GPa}$ & $650-670$ & $\begin{array}{l}\text { Inclusion of Ph, Grt } \\
\text { (Rim1, 2, and 3), Pg }\end{array}$ & $\begin{array}{l}\text { Grt, Ep, and Rt Qz- } \\
\text { mica schist }\end{array}$ \\
\hline & FG12157 & 2 & $64.5 \pm 4.3$ & $65-60$ & $1.55-1.65 \mathrm{GPa}$ & $630-670$ & Inclusion of $\mathrm{Ph}$ & $\begin{array}{l}\text { Grt, Gln, Ep, and Rt } \\
\text { mica schist }\end{array}$ \\
\hline & FG1347 & 3 & $55.7 \pm 4.5$ & $56 \pm 4$ & $1.8-2 \mathrm{GPa}$ & $580-610$ & Inclusion of $\mathrm{Ph}, \mathrm{Pg}, \mathrm{Rt}$ & $\begin{array}{l}\text { Cld, Grt, and Rt } \\
\text { mica schist }\end{array}$ \\
\hline & FG1249 & 1 & $72.5 \pm 1.4$ & - & $1.55-1.65 \mathrm{GPa}$ & $580-630$ & Inclusion of $\mathrm{Ph}, \mathrm{Pg}$ & $\begin{array}{l}\text { Grt, Ep, and Rt } \\
\text { mica schist }\end{array}$ \\
\hline \multirow{2}{*}{ U } & FG1420 & 4 & $73.7 \pm 8.2$ & - & $0.5-0.8 \mathrm{GPa}$ & $400-500$ & Inclusion of $\mathrm{Ph}, \mathrm{Pg}$, Ttn & Grt orthogneiss \\
\hline & FG12107 & 4 & $62.8 \pm 3.3$ & - & no $P$ & no $T$ & Inclusion of $\mathrm{Ph}, \mathrm{Pg}$ & $\begin{array}{l}\mathrm{Ep}, \mathrm{Ph} \text {, and } \mathrm{Ab} \\
\text { leucogneiss }\end{array}$ \\
\hline
\end{tabular}

the development of the main foliation. In samples FG1347 and FG1249 allanite includes phengite and paragonite; in FG12157 allanite includes only phengite. These micas have the same composition as those defining the eclogite foliation (Fig. 7b-d). In the cases of FG1249 and FG1347, allanite also shows intergrowths with both white micas (Fig. 7c).

In the EC, allanite is rare and, where present, is typically magmatic; it appears dark brown and pleochroic in the optical microscope, with a grain size of some millimetres (Fig. 2h; Giuntoli and Engi, 2016). In only two samples was metamorphic allanite found, preserved in the core of epidote crystals (FG1420, FG12107). The metamorphic allanite has a grain size of less than $50 \mu \mathrm{m}$ and is colourless or pale yellow in polarized light, with low interference colour and undulose extinction in crossed polarized light. Sample FG1420 shows both magmatic and metamorphic allanites (Fig. 7g, h). Allanite includes paragonite, with phengite and titanite occurring both in the epidote rim and at the allanite-epidote boundary (Fig. 7g). Very few tiny monazite grains (a few micrometres) are found in the core of metamorphic allanite. Sample FG12107 also shows similar epidote crystals preserving metamorphic allanite in their core, as in sample FG1420. Magmatic allanite preserved in sample FG1420 occurs as mm-size grains that are fractured and appear much brighter in BSE pictures than metamorphic allanite (Figs. 2h, 7h). Epidote crystals form satellites around magmatic allanite, suggesting partial breakdown (Fig. 7h). Note that these epidote crystals retain a BSE bright core of newly grown (Alpine) metamorphic allanite.

\subsection{Results: allanite U-Th-Pb dating}

For both IC and EC, only allanite cores were successfully dated. The rims showed too high common lead $\left(\mathrm{Pb}_{\mathrm{c}}\right)$ contents, the correction (Gregory et al., 2007; Burn et al., 2017) of which would lead to large uncertainties in the age calculation.

In the IC and EC, the Tera-Wasserburg and ${ }^{232} \mathrm{Th} /{ }^{206} \mathrm{~Pb}_{\mathrm{c}}-{ }^{208} \mathrm{~Pb} /{ }^{206} \mathrm{~Pb}_{\mathrm{c}}$ isochron diagrams are concordant, within the range of uncertainty, in all the analysed samples (Figs. 8, 9; every ellipse is a single spot measurement). Ages range between 77 and $56 \mathrm{Ma}$ for the allanite cores of the IC. In the EC, the magmatic allanite cores in sample FG1420 yield ages of $\sim 290 \mathrm{Ma}$, and the metamorphic cores yield ages of $73.7 \pm 8.2 \mathrm{Ma}$. In sample FG12107, the metamorphic allanite cores were dated to $62.8 \pm 3.3 \mathrm{Ma}$. A summary of the Alpine allanite age data from each sample is listed in Table 5 .

In detail, the IC Tera-Wasserburg diagrams show ${ }^{207} \mathrm{~Pb} /{ }^{206} \mathrm{~Pb} y$ intercepts of $0.84 \pm 0.01,0.823 \pm 0.018$, and $0.83 \pm 0.004$ for samples FG1324, FG1315, and FG12157, respectively, with a MSWD on the regression between 1.2 and 2.1 (Fig. 8). ${ }^{206} \mathrm{~Pb}_{\mathrm{c}}$-isochron diagrams display a ${ }^{208} \mathrm{~Pb} /{ }^{206} \mathrm{~Pb} y$ intercept of $2.081 \pm 0.027,2.077 \pm 0.066$, and $2.085 \pm 0.028$ for samples FG1324, FG1315, and FG12157, respectively, with a MSWD on the regression between 0.46 and 0.98 . These values are close to the predicted values of Stacey and Kramers (1975) for model lead evolution of this time range (Fig. 1 in Burn, 2016). The exception is sample FG1347, in which the Tera-Wasserburg diagram shows a ${ }^{207} \mathrm{~Pb} /{ }^{206} \mathrm{~Pb} y$ intercept at $0.787 \pm 0.04$ (MSWD on the regression of 2.5) and displays a ${ }^{208} \mathrm{~Pb} /{ }^{206} \mathrm{~Pb} y$ intercept on the ${ }^{206} \mathrm{~Pb}_{\mathrm{c}}$-isochron diagram at $1.98 \pm 0.082$ (MSWD on the regression of 0.4 ). These values deviate from the values predicted by Stacey and Kramers (1975), probably indicating local inheritance.

In the EC, data for magmatic allanite in sample FG1420 show a ${ }^{207} \mathrm{~Pb} /{ }^{206} \mathrm{~Pb} y$ intercept at $0.85 \pm 0.11$ in a TeraWasserburg diagram and display a ${ }^{208} \mathrm{~Pb} /{ }^{206} \mathrm{~Pb} y$ intercept at $2.09 \pm 2.7$ in a ${ }^{206} \mathrm{~Pb}_{\mathrm{c}}$-isochron diagram (Fig. 9). 


\section{Age Data - Internal Complex Tera-Wasserburg diagram Sample Th-isochron diagram FG 1324}
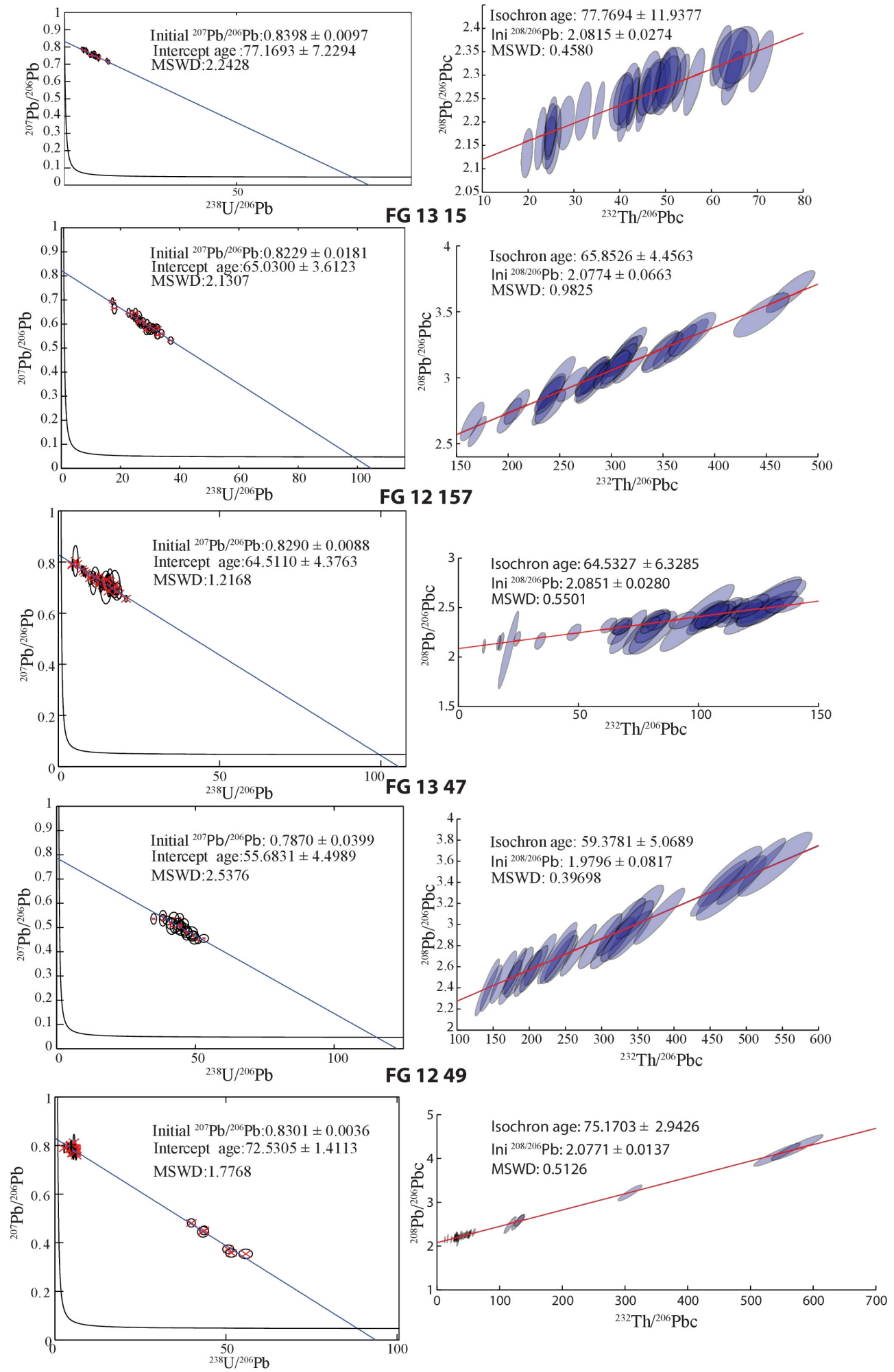

Figure 8. Results of the IC samples plotted in the Tera-Wasserburg and ${ }^{232} \mathrm{Th} /{ }^{206} \mathrm{~Pb}_{\mathrm{c}}-{ }^{208} \mathrm{~Pb} /{ }^{206} \mathrm{~Pb}_{\mathrm{c}}$ isochron diagram with intercept and isochron age, respectively, and initial common lead composition estimations. 


\section{Age Data - External Complex \\ Tera-Wasserburg diagram Sample Th-isochron diagram}
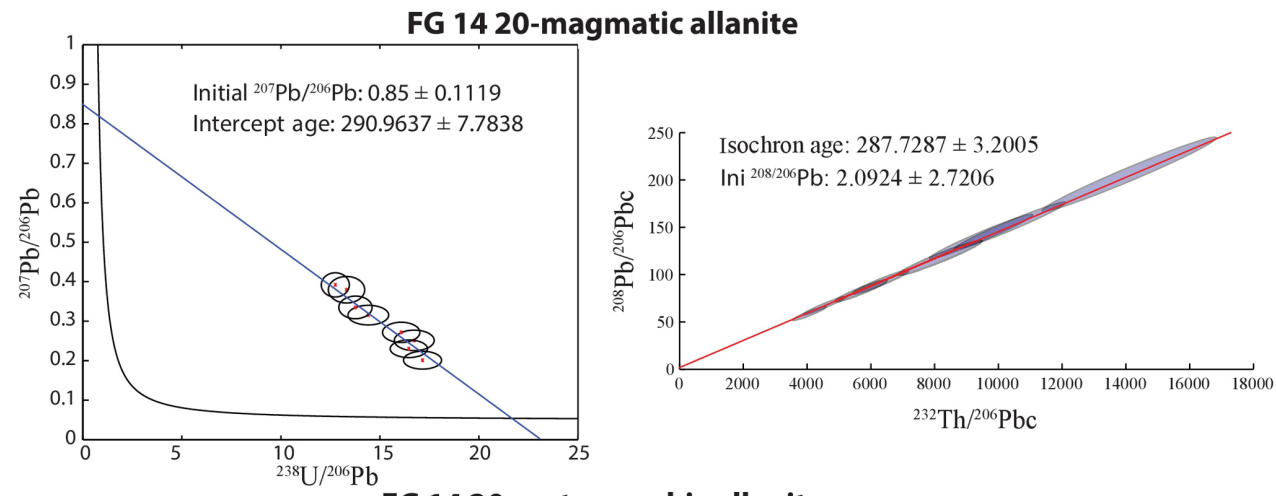

FG 14 20-metamorphic allanite
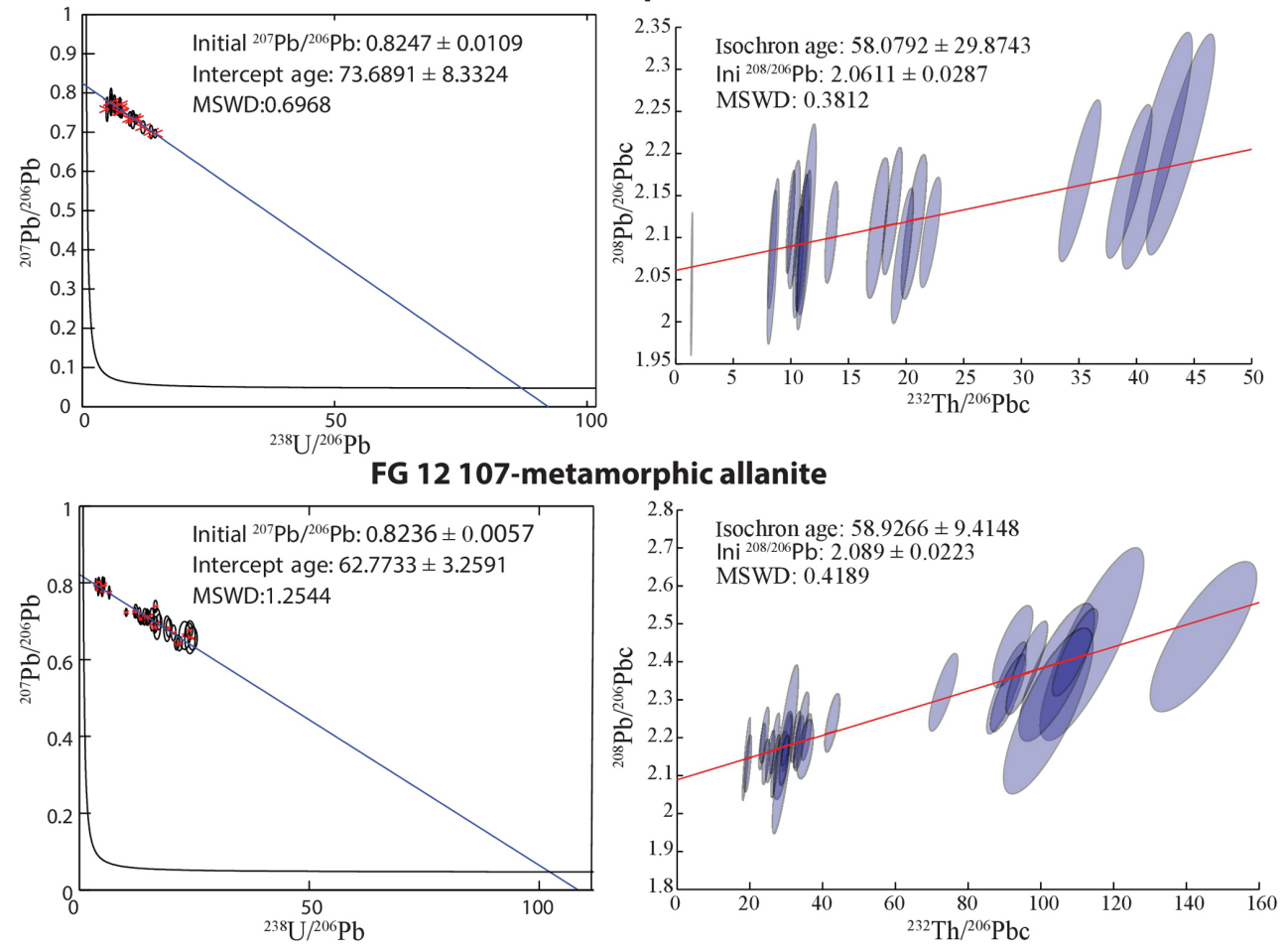

Figure 9. Results of the EC samples plotted in the Tera-Wasserburg and ${ }^{232} \mathrm{Th} /{ }^{206} \mathrm{~Pb}_{\mathrm{c}}-{ }^{208} \mathrm{~Pb} /{ }^{206} \mathrm{~Pb}$ isochron diagram with intercept and isochron age, respectively, and estimated initial common lead composition.

These large uncertainties reflect few (eight) spots analyses. Metamorphic allanites show ${ }^{207} \mathrm{~Pb} /{ }^{206} \mathrm{~Pb} y$ intercepts of $0.825 \pm 0.01$ and $0.824 \pm 0.006$ in Tera-Wasserburg diagrams (MSWD on the regression of 0.7 and 1.2) and display ${ }^{208} \mathrm{~Pb} /{ }^{206} \mathrm{~Pb} y$ intercepts of $2.061 \pm 0.029$ and $2.089 \pm 0.022$ in ${ }^{206} \mathrm{~Pb}_{\mathrm{c}}$-isochron diagrams (MSWD on the regression of 0.4) for samples FG1420 and FG12107, respectively. These values are close to the predicted values of Stacey and Kramers (1975) for these time ranges.

\subsection{Results: zircon textures}

Internal textures of zircon from the IC reveal complex zoning in CL images (Fig. 10), showing detrital cores and several phases of resorption and (metamorphic) overgrowth. Zircon cores commonly preserve a variety of internal textures, most commonly oscillatory zoning (Fig. 10e, f), which is typical of zircon-grown form melt. Many cores are affected by resorption, obliterating earlier features, but some grains show sharp boundaries between core and rims, and these preserve features of sediment transport such as broken, rounded, or pitted surfaces (Fig. 10b). The number of rims varies among 


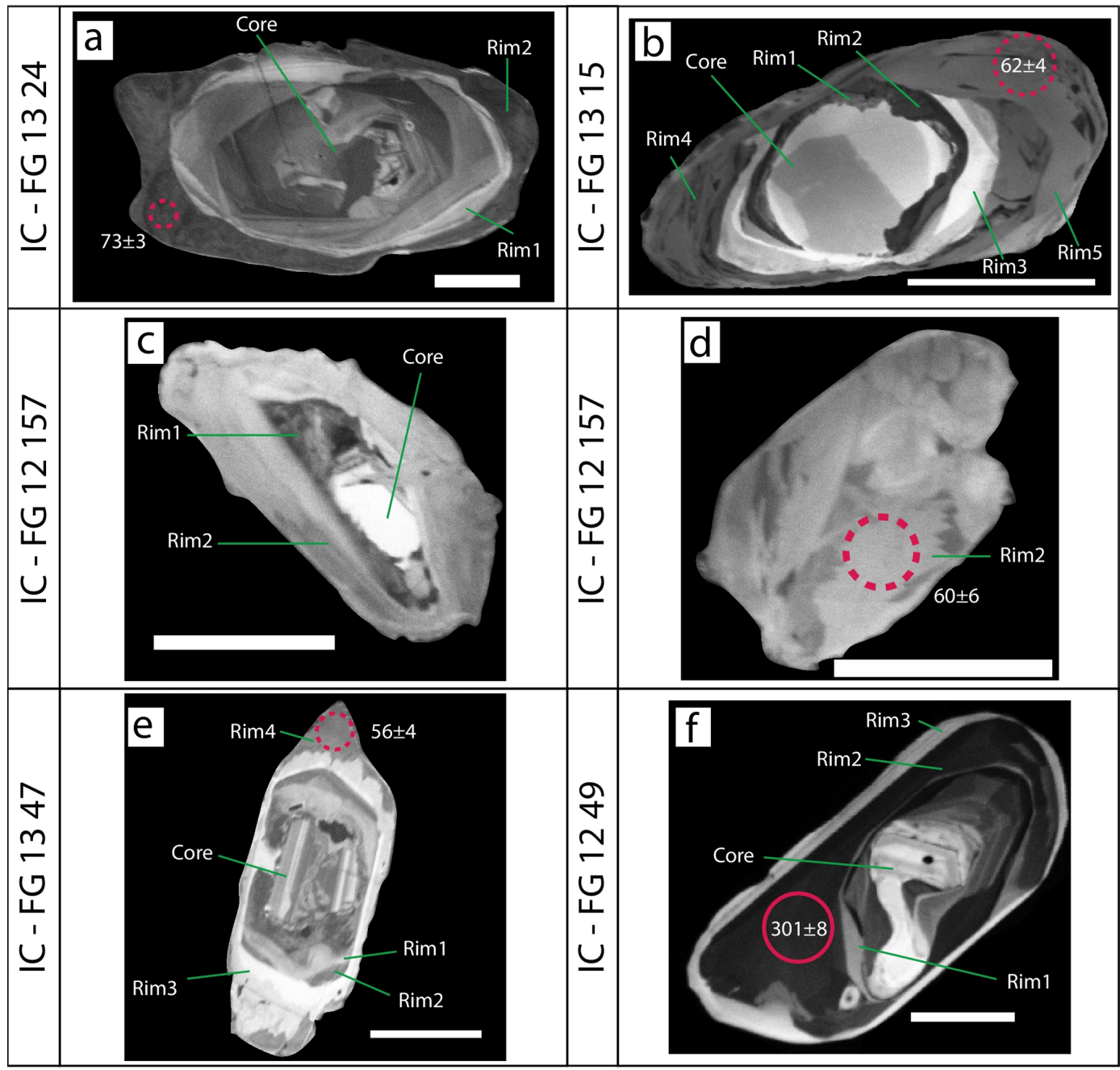

Figure 10. CL images of zircon textures in the samples from the Internal Complex. Typically detrital cores show more or less resorption and are followed up by one to five metamorphic rim generations of different CL responses. The scale bar in all images is $50 \mu \mathrm{m}$. Solid circles correspond to $32 \mu \mathrm{m}$ LA-ICP-MS spots, while dashed circles are $16 \mu \mathrm{m}$ spot sizes. The dates are individual ${ }^{206} \mathrm{~Pb} /{ }^{238} \mathrm{U}$ spot analysis given in Ma.

and within samples, from two rims in sample FG1257 to a maximum of five in FG1315. Most zircon grains show a first metamorphic rim with a light grey to bright CL response, followed by a rim with dark CL appearance. The third rim is again typically medium grey to bright white in CL. In sample FG1315, a fourth (dark CL) and fifth (light grey) rim follow, and FG1347 occasionally shows a CL-dark fourth rim. The internal textures of the different rims are not always clearly distinguishable, either because of limited width or, in the case of a very dark or bright CL response, limited contrast. The second metamorphic rim in FG12157 is either uniform or shows fir-tree zoning (Vavra et al., 1996; Root et al., 2004). In sample FG1347 metamorphic rims are often too thin to distinguish or no texture is recognizable in the bright CL third rim. The first two rims in sample FG1315 have cloudy textures; the third rim with the bright-CL shows no further internal textures but sometimes has inclusions and the two outermost rims commonly are uniform or cloudy in texture. The innermost and outermost metamorphic rims in samples FG1249 and FG1324 are bright and featureless; the second dark rim in sample FG1249 shows sector zoning and many inclusions. The third (medium grey) rim in FG1249 has a cloudy texture.

Zircon in the EC displays pre-Alpine magmatic oscillatory zoning, rarely shows a bright CL rim, is $5-10 \mu \mathrm{m}$ in width, and surrounds the core.

\subsection{Results: zircon U-Pb dating}

The range of Alpine ${ }^{206} \mathrm{~Pb} /{ }^{238} \mathrm{U}$ zircon dates for each sample are summarized in Table 5. Details on the pre-Alpine dates are available in Kunz et al. (2017). Supplement S10 gives an overview of pre-Alpine dates as well as individ- 
ual analyses of Alpine dates. Concordia plots of individual spot analyses of Alpine zircon are available in Supplement S11. For the five samples we obtained 27 analyses of detrital cores, 53 of Permian rims, and 34 of Alpine rims. Detrital zircon cores in samples from the IC range from $\sim 793$ to $353 \mathrm{Ma}$ and partially overlap with the first rim in samples FG1324 and FG1249 (Fig. 10), for which the dates range from $\sim 450$ to $420 \mathrm{Ma}$. In most samples, at least two rims are found yielding Carboniferous to Triassic dates from $\sim 313$ to $222 \mathrm{Ma}$, as discussed in detail by Kunz et al. (2017); only one sample (FG1324) shows none of these. Alpine rims, with a range between 77 and $56 \mathrm{Ma}$, were measured in all samples except FG1249, in which the third rim was too thin $(10 \mu \mathrm{m})$ to be analysed. No correlation was found between rim types and ages within samples or amongst them, and it was not possible to make absolute age distinctions among Alpine rim generations. This is due to relatively large uncertainty in the ages, as the narrow rims only allowed small spots for LAICP-MS measurements, decreasing their analytical precision.

$\mathrm{Th} / \mathrm{U}$ ratios in detrital zircon cores range between 0.15 and $>3$; the rim generation with dates between 450 and 420 Ma have low Th / U ratios in sample FG1324 (0.0060.14 ) whereas those in sample FG1249 are between 0.1 and 0.5. The Carboniferous to Triassic rims show $\mathrm{Th} / \mathrm{U}$ ratios between 0.002 and 0.4. The Alpine metamorphic rims show low $\mathrm{Th} / \mathrm{U}$ ratios between 0.001 and 0.01 .

\section{Discussion}

\subsection{Linking time constraints with equilibrium conditions (petrochronology)}

Preliminary analysis of allanite for U-Th-Pb using LA-ICPMS was performed in situ (i.e. using LA-ICP-MS spot analyses) on polished thin sections. However, to obtain more material for dating, allanite grains were subsequently separated, mounted on resin mounts, and polished. The main reasons why allanite grains were separated for dating are as follows.

- Grain mounts are more efficient as they enable the selection of more spots to analyse a single growth zone (at least 1 order of magnitude more spot analyses per sample than in thin sections).

- Grains mounts produce more likely equatorial cuts because polishing is optimized to obtain the largest sections possible at a given grain size. This is essential for LA-ICP-MS analysis of grains with several growth zones: if sectioning is not near-equatorial, one is more likely to drill through different growth zones.

We do consider petrographic control before dating to be essential: all mounts were imaged using SEM with the BSE detector to document allanite textures. For each sample, both in the thin section and in the mounts, the allanite grains displayed the same textural patterns, growth zones, and mineral inclusions on the sample scale (in separates and thin section). The microtextural features observed in thin sections were readily linked to those seen in grain mounts (compare Fig. 7a and f). Furthermore, we note that $\mathrm{U}-\mathrm{Th}-\mathrm{Pb}$ ages from grain mount analyses agree within uncertainty with the spot analyses made in thin sections.

The fundamental task to reconstruct the $P-T-t$ paths is to establish a strong link between $P$ and $T$ conditions, derived from thermodynamic modelling, and $t$ data, derived from age dating. Several criteria were used to achieve this goal, notably (i) textural evidence, (ii) the presence and composition of distinctive minerals as inclusions, and (iii) the presence of intergrowths of allanite with other phases.

As described in Sect. 6.2, allanite grains of the IC are intergrown with the main mineral phases that describe the eclogite facies foliation (Fig. 7; Table 5). Furthermore, the compositions of mineral inclusions in allanite matched those found in the matrix and those predicted by thermodynamic modelling (representative chemical analyses in Supplement S5). Based on these observations (and details given in Sect. 6.2 for each sample), we infer growth of allanite coeval with the minerals marking the eclogite facies foliation in all of the samples analysed from the IC. This link between age data and $P-T$ conditions is shown by the red ellipses on the equilibrium phase diagrams shown in Fig. 4 and on the $P-T-t$ paths shown in Fig. 11b and c (colour-coded for each sample). Additionally, in four samples of the IC, the ages obtained for allanite cores and Alpine zircon rims overlap within uncertainty, suggesting coeval growth of these two accessory minerals.

In the EC, metamorphic allanite is rare and preserved only in the core of epidote (Sect. 6.2; Fig. 7g, h). Epidote is intergrown with white mica, chlorite, and titanite, marking the retrograde greenschist overprint, which is constrained by chlorite + white mica + quartz $+\mathrm{H}_{2} \mathrm{O}$ thermobarometry $\left(\sim 0.9 \mathrm{GPa}\right.$ and $350^{\circ} \mathrm{C}$ to $0.4 \mathrm{GPa}$ and $230^{\circ} \mathrm{C}$; see Fig. 6 ). According to these results, metamorphic allanite growth in the EC predates the retrograde greenschist overprint (red ellipse in Fig. 4f and purple ellipse in Fig. 11b-c).

\section{2 $\quad P-T-t$ paths of samples}

\subsubsection{Pre-Alpine conditions in the IC}

The history of the studied samples is summarized in $P-T-$ $t$ diagrams (Fig. 11) and compared with relevant data from the literature. The first metamorphic stage recorded in our samples from the IC is of Permian age; it reflects granulite facies conditions. Porphyroclastic garnet cores (present in samples FG1315, FG12157, FG1347, and FG1249) are the only major mineral relics of this HT stage. Among accessory minerals, late Carboniferous to Upper Triassic zircon rims (between 313 and $222 \mathrm{Ma}$ ) are preserved, and monazite relics in allanite are most probably Paleozoic as well. The ages of the Permian zircon cores fit well with those reflect- 
(a) Literature PTt paths

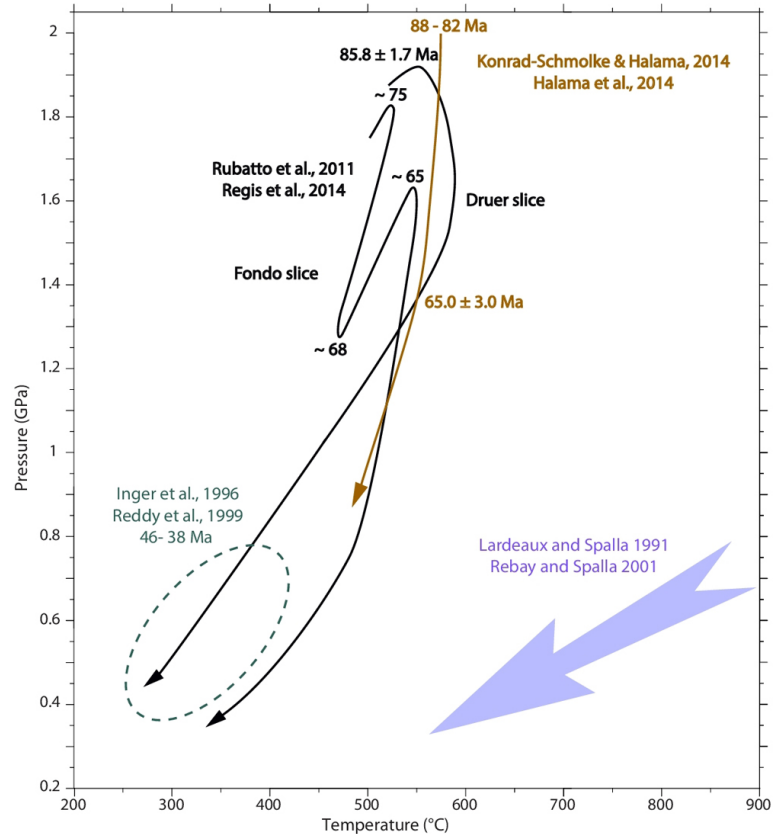

(c) Interpretation

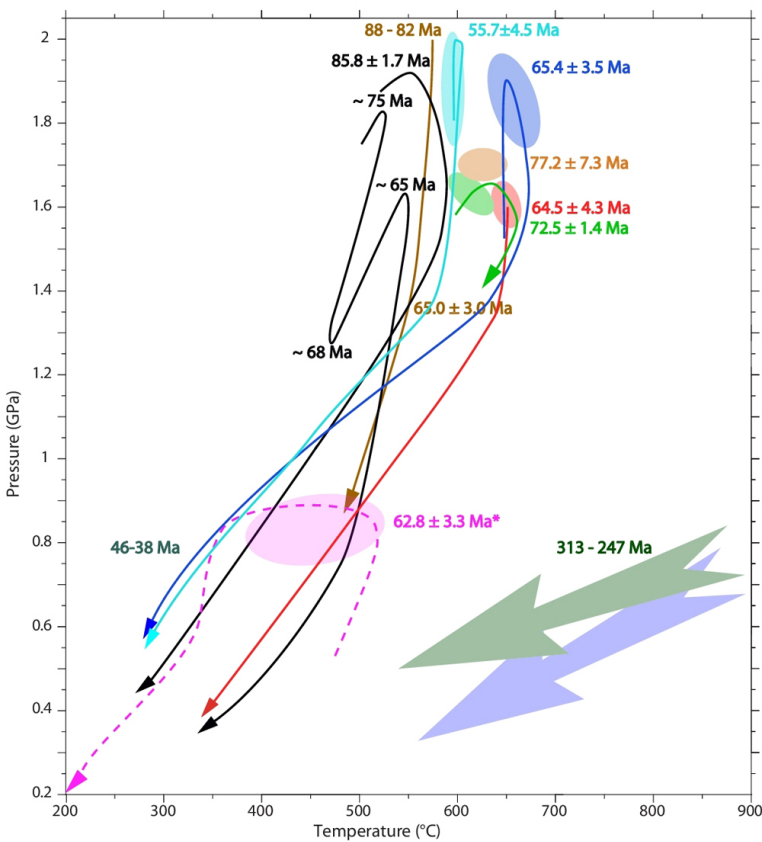

(b) This study

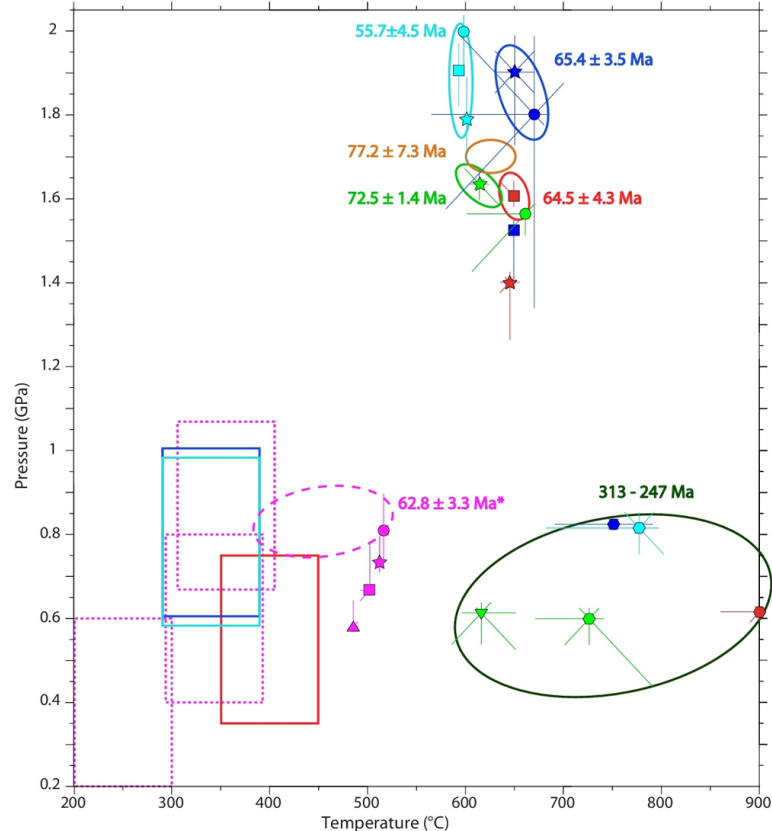

\section{Legend}

PT constraints for age data

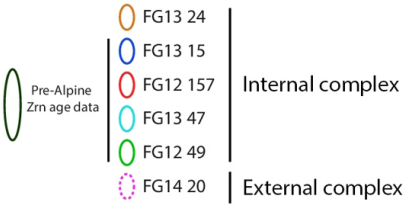

Garnet growth zones

Pre-Alpine

$\bigcirc$ CORE

$\nabla$ RIM1 FG 1315

Alpine $\begin{aligned} & \text { FG } 12157 \\ & \text { FG } 1347\end{aligned}$

RIM1 $\mathrm{FG} 1249$

RIM2

$\mathrm{Chl}-\mathrm{Wm}\left( \pm 2 \mathrm{GPa} ; \pm 50^{\circ} \mathrm{C}\right)$

D FG 1315

( $\left.0.8 \mathrm{GPa}-340^{\circ} \mathrm{C}\right)$

—FG 12157

$\left(\sim 0.54 \mathrm{GPa}-400^{\circ} \mathrm{C}\right)$

D FG 1347

$\left(\sim 0.78 \mathrm{GPa}-340^{\circ} \mathrm{C}\right)$

FG 1420

( $\left.0.87 \mathrm{GPa}-350^{\circ} \mathrm{C} ; 0.6 \mathrm{GPa}-330^{\circ} \mathrm{C} ; 0.4 \mathrm{GPa}-230^{\circ} \mathrm{C}\right)$

PTt paths

IC-Permian cooling, this study

L2 IC- Permian cooling, Lardeaux \& Spalla 1991; Rebay \& Spalla 2001

Figure 11. $P-T-t$ paths of the study area (Fig. 1). (a) Data and paths from previous studies: proposed pre-Alpine evolution from the data of Lardeaux and Spalla (1991) and Rebay and Spalla (2001); Alpine evolution of the Internal Complex from Rubatto et al. (2011), Regis et al. (2014), Konrad-Schmolke and Halama (2014), and Halama et al. (2014); ages for the External Complex are from Inger et al. (1996) and Reddy et al. (1999), related to greenschist facies conditions. (b) Data presented in this study. Ellipses show $P-T$ constraints for the age data; rectangles refer to retrograde stages. Error bars show the $P-T$ uncertainty related to the analytical error of the garnet composition. (c) Interpreted $P-T-t$ paths. Full lines: Internal Complex; dashed lines: External Complex. The star indicates the age data from sample FG12107 (see text for explanation).

ing HT metamorphism in the Ivrea Zone and Adria-derived units in the western Alps (Vavra et al., 1996, 1999; Ewing et al., 2013; Kunz et al., 2017), thus supporting the long-held view that the Sesia Zone is closely related to the Ivrea Zone (e.g. Compagnoni et al., 1977). The single Upper Triassic date $(222 \pm 13 \mathrm{Ma})$ in sample FG1315 is similar to ages re- 
ported by Vavra et al. (1999) from the Ivrea Zone, where they have been related to fluid alteration. The $P-T$ conditions for the pre-Alpine HT stage are constrained between 0.6 and $0.8 \mathrm{GPa}$ and between 700 and $900{ }^{\circ} \mathrm{C}$ from the garnet cores of the IC samples. These results confirm earlier data for the IC $\left(0.6-0.9 \mathrm{GPa}, \sim 850^{\circ} \mathrm{C}\right.$; Lardeaux and Spalla, 1991; Rebay and Spalla, 2001; Fig. 11). A retrograde preAlpine path through amphibolite facies conditions is evident in sample FG1249, where a first garnet rim generation yields $\sim 0.6 \mathrm{GPa}$ and $600^{\circ} \mathrm{C}$ (Fig. 11b), again in fair agreement with previous data $\left(0.3-0.5 \mathrm{GPa}, 570-670^{\circ} \mathrm{C}\right.$; Lardeaux and Spalla, 1991; Rebay and Spalla, 2001). A sketch summarizing the chronology and thermodynamic modelling of garnet in sample FG1249 is shown in Giuntoli et al. (2018).

\subsubsection{Pre-Alpine conditions in the EC}

In the EC, sample FG1420 shows pre-Alpine ages of $\sim 290$ Ma for the magmatic allanite grains. These age data probably reflect magmatic crystallization ages of the granitoids; they are in good agreement with several age data of magmatic zircon and monazite for the Sesia-Dent Blanche nappe (Fig. 1 in Bussy et al., 1998; Table 2 and Fig. 5 in Kunz et al., 2017).

\subsubsection{Alpine conditions in the IC}

For the Alpine history, our samples from the IC indicate higher $P$ and $T$ than in the EC, based on detailed garnet compositional modelling (Lanari et al. 2017). The IC recorded a range of maximum pressures between 1.6 and $2 \mathrm{GPa}$ at temperatures of $600-670^{\circ} \mathrm{C}$. Age constraints based on allanite dating of five samples from the IC fall into three groups including

- Group 1 with ages of $\sim 73 \mathrm{Ma}$ (from 77.2 $\pm 7.3 \mathrm{Ma}$ to $72.4 \pm$ 1.4 Ma, based on samples FG1324 and FG1249, respectively);

- Group 2 at $\sim 65 \mathrm{Ma}$ (from $65.4 \pm 3.5 \mathrm{Ma}$ to $64.5 \pm 4.3 \mathrm{Ma}$, based on samples FG1315 and FG12157);

- Group 3 at 55.7 $\pm 4.5 \mathrm{Ma}$ (sample FG1347).

Metamorphic conditions for Group 1 show 1.6-1.75 GPa and $580-650^{\circ} \mathrm{C}$ for the earliest stage. In Group 2, samples FG1315 and FG12157 yield not only the same age, within analytical uncertainty, but also similar metamorphic conditions; the pressure difference of $0.1-0.2 \mathrm{GPa}$ is within the uncertainty of the model, as indicated by error bars in Fig. $11 \mathrm{~b}$. Notably, the same $P-T$ conditions were derived from garnet rim1 of FG12157 in Group 2 and from garnet rim3 of sample FG1249 in Group 1. Summarizing, Groups 1 and 2 experienced similar $P-T$ conditions but Group 2 attained these some 5-10 Myr later. Furthermore, the outermost garnet rim in sample FG12157 preserves evidence of a retrograde stage at $1.4 \mathrm{GPa}$ and $650^{\circ} \mathrm{C}$. Sample FG1347 (Group 3) shows the youngest allanite ages for a similar pressure range as Groups 1 and 2 but lower temperature conditions $(\sim 580$ $600^{\circ} \mathrm{C}$ ). It thus appears that the samples from the IC reflect several stages of allanite growth, probably because rocks of slightly different bulk composition produced allanite by different metamorphic reactions (Engi, 2017). Three growth stages captured in our samples are at $\sim 73, \sim 65$, and $\sim 56 \mathrm{Ma}$. The different $P-T-t$ paths of Groups 1,2 , and 3 are interpreted to represent different tectonic sheets (Giuntoli and Engi, 2016) that experienced similar $P-T$ conditions but at different times (further discussed in Sect. 7.3).

Regis et al. (2014; Druer slice) and Konrad-Schmolke and Halama (2014) suggested similar $P-T$ paths for different parts of the IC (Fig. 11c), with the highest pressure reached at $\sim 85 \mathrm{Ma}$. Halama et al. (2014) constrained the development of the retrograde blueschist facies Tallorno Shear Zone (Konrad-Schmolke et al., 2011) at 65.0 \pm 3.0 Ma using ArAr data on phengite. This shear zone was related to external fluid influx occurring at approximately $1.35 \mathrm{GPa}$ and $550^{\circ} \mathrm{C}$ (Konrad-Schmolke and Halama, 2014). These two $P-T$ paths are similar to Group 3 of the present study, but the latter are up to $30 \mathrm{Myr}$ younger. Groups 1 and 2 consistently display similar $P-T$ paths, but temperatures are 50 $100^{\circ} \mathrm{C}$ higher than those determined by Regis et al. (2014) and Konrad-Schmolke and Halama (2014). In our samples from the IC, we detected no evidence of pressure cycling such as documented by Rubatto et al. (2011) further south, in the Fondo slice (Regis et al., 2014).

\subsubsection{Alpine conditions in the EC}

In sample FG1420, metamorphic allanites yield ages of $73.7 \pm 8.2 \mathrm{Ma}$ associated with metamorphic conditions of $0.8 \mathrm{GPa}$ and $350-500^{\circ} \mathrm{C}$, a stage constrained by the growth of garnet and phengite, the mica marking the main foliation. Sample FG12107 yields an allanite growth age of $62.8 \pm 3.3 \mathrm{Ma}$ (Fig. 11c highlighted by the star). Chlorite and white mica data from this sample give thermobarometric results in agreement with FG1420. The proximity of the two samples in the field and their similarity in $P-T$ conditions and in textural features of allanite lead us to suggest that allanite grew at the same metamorphic stage in these two samples. Their (nominal) ages seem discrepant, but considering the overlapping $(2 \sigma)$ uncertainties, we view them as a single age group (Group 4: $\sim 63 \pm 3 \mathrm{Ma}$ ).

\subsubsection{Comparison of $\boldsymbol{P}-\boldsymbol{T}-\boldsymbol{t}$ data for the IC and EC}

Comparing $P-T-t$ data for the IC and EC, we note that Group 2 (in the IC) and Group 4 (in the EC) recorded the same age data of ca. $65 \mathrm{Ma}$, but very different metamorphic conditions. This implies that the IC and EC at that time were at a completely different structural position in the subduction zone: a difference of $1 \mathrm{GPa}$ translates to a $\sim 30 \mathrm{~km}$ ver- 
tical offset between the two complexes, assuming lithostatic pressures. Tectonic overpressure cannot be ruled out, but it cannot explain the observed difference in pressures since Group 4 (at $0.8 \mathrm{GPa}$ ) also displays $\sim 150^{\circ} \mathrm{C}$ lower temperatures compared to Group 2 (at 1.6-1.8 GPa). We conclude that the IC resided in a substantially deeper and hotter part of the subduction system than the EC $\sim 65 \mathrm{Myr}$ ago.

The retrograde $P-T$ trajectories in the IC and EC are similar based on our data for chlorite-white mica equilibria: $\sim 0.8 \mathrm{GPa}$ and $340^{\circ} \mathrm{C}$ for samples FG1315, FG1347 (IC), and FG1420 (EC; Fig. 11b). Sample FG12157 recorded a low-pressure stage at slightly higher temperature $(0.54 \mathrm{GPa}$ and $393^{\circ} \mathrm{C}$ ) compared to the two other samples of the IC. The EC records two further retrograde stages at $0.60 \mathrm{GPa}$ and $330^{\circ} \mathrm{C}$ and at $0.42 \mathrm{GPa}$ and $220^{\circ} \mathrm{C}$. However, these retrograde stages have yet to be precisely dated. Inger et al. (1996) and Reddy et al. (1999) constrained the greenschist facies overprint of the EC between 46 and $38 \mathrm{Ma}(\mathrm{Rb}-\mathrm{Sr}$ using phengite). In light of our data, we interpret these ages to reflect the greenschist facies conditions documented in both complexes (constrained between $\sim 0.8 \mathrm{GPa}$ and $400^{\circ} \mathrm{C}$ and $0.4 \mathrm{GPa}$ and $\left.300^{\circ} \mathrm{C}\right)$. The allanite core ages in Group 4 would then be related to an earlier deformation event, as the epidote rim marks the greenschist overprint (Figs. 7g, 11c). Zircon fission track ages for the Sesia Zone range from 42 to $26 \mathrm{Ma}$ (Wagner and Reimer, 1972; Hurford and Hunziker, 1985; Hurford et al., 1989, 1991; Kapferer, 2010; Berger et al., 2012), suggesting that the terrain crossed the $\sim 250^{\circ} \mathrm{C}$ isotherm in this age range during exhumation. For the most internal section of the Sesia terrain, the overlying Biella Volcanic Suite dated at 32.5 Ma (Kapferer, 2010; Kapferer et al., 2012) provides an age constraint for the final exhumation to the surface.

\subsection{Tectonic assembly and exhumation of the Sesia Zone}

The IC shows several tectonic sheets, from several hundred metres to a few kilometres in thickness (Giuntoli and Engi, 2016), some of which moved independently in the subduction channel (Rubatto et al., 2011; Regis et al., 2014) at some stages of the evolution. Some of the samples we studied, while taken at most a few kilometres apart in the field, recorded similar $P-T$ paths at different times, as reflected by the three age groups identified (Fig. 1b, c). This age difference may reflect relative tectonic mobility at eclogite facies conditions between such sheets of basement-derived rocks, which are notoriously difficult to delimit in this terrain (Giuntoli and Engi, 2016). In addition to tectonic mobility, the combined effects of deformation and repeated hydration must be considered as triggers of recrystallization that promoted chemical equilibration to eclogite facies assemblages (including allanite and zircon, as discussed below).

The differences in the $P-T$-conditions (at eclogite facies) documented above for the IC samples do not indicate tra- jectories as tortuous as those suggested by numerical models for ablative subduction (e.g. Stöckhert and Gerya, 2005; Roda et al., 2012). Our $P-T-t$ data as well as the nature and geometry of tectonic boundaries mapped by Giuntoli and Engi (2016) rather indicate progressive accretion at depths of $50-60 \mathrm{~km}$, probably during final subduction-early exhumation stages, juxtaposing a series of continental sheets and forming a coherent complex (the IC; Vitale Brovarone et al., 2013; Regis et al., 2014). Eclogite facies conditions in the IC evidently prevailed for an extended period, at least $\sim 15 \mathrm{Myr}$.

In the IC, the main deformation stages and mineral reactions were related to pulses of external fluid passing through the rocks, as reported by Engi et al. (2018) and Giuntoli et al. (2018). Repeated fluid influx occurred under eclogite facies conditions, as shown by resorption and growth features in garnet and zircon, with hydrous fluid pervasively rehydrating rocks that had previously been almost completely dehydrated by upper Paleozoic metamorphism (Engi et al., 2018). Thus Permian kinzigites (granulite facies metapelites) were transformed back to mica schists during Alpine subduction. As allanite and zircon ages from these samples are identical within analytical uncertainties, it appears that this fluid influx also triggered the coeval growth of accessory phases under eclogite facies conditions. Later and more localized fluid influx has also been documented in blueschist facies conditions (Konrad-Schmolke et al., 2011), and this probably continued to greenschist facies conditions, as reflected by the partial overprint of the main eclogite assemblages, which is frequently observed in the IC. Our samples in the IC indicate higher temperatures than have been previously reported (Fig. 11). This discrepancy may reflect a regional thermal gradient, namely higher temperatures in more external areas (NW) of the IC, but we suspect it to be a direct effect of the (re)hydration of pre-Alpine HT rocks, which is an exothermic process (e.g. Walther and Orville, 1982; Peacock, 1987; Lyubetskaya and Ague, 2009). Walther and Orville (1982) analysed the thermal effects of (de)hydration reactions during regional metamorphism and found them to be substantial. When applied to the present situation of (re)hydration, heat capacity data indicate that heating the HT Permian protolith requires $\sim 1.0 \mathrm{~kJ} \mathrm{~K}^{-1} \mathrm{~kg}^{-1}$ of leucogneiss. The enthalpy released upon partial hydration of this protolith (producing the water content typical of these mica schists, $1.5 \mathrm{wt} \% \mathrm{H}_{2} \mathrm{O}$ ) adds $\sim 77 \mathrm{~kJ} \mathrm{~kg}^{-1}$ in enthalpy. Such hydration should thus result in a temperature increase of some $80^{\circ}$. This estimate lends credibility to the $P-T$ estimates obtained here, which are indeed $20-80^{\circ} \mathrm{C}$ higher than some maximum temperatures recently reported from other parts of the Sesia Zone, e.g. $575^{\circ} \mathrm{C}$ (Konrad-Schmolke and Halama, 2014), 570-630 ${ }^{\circ} \mathrm{C}$ for the Druer Slice (Regis et al., 2014), or $>600^{\circ} \mathrm{C}$ for the Ivozio Complex (Zucali and Spalla, 2011). In addition, Zr-in-rutile data reported by Kunz et al. (2017, their Table 3) gave $640^{\circ} \mathrm{C}$ for one of the present samples (FG1249), confirming our results by an entirely independent method. 
Table 6. Exhumation velocities for Groups 1 and 3 (IC) from the highest pressures recorded to the greenschist juxtaposition with the EC (Stage1) and for the late exhumation to the surface of the Sesia Zone (INT-EXT; Stage2).

\begin{tabular}{|c|c|c|c|c|c|}
\hline & & Age at $\sim 0.6 \mathrm{GPa}$ & $\begin{array}{l}\text { Vertical velocity } \\
\text { mm year }^{-1}\end{array}$ & $\begin{array}{l}\text { Along sub. inter. } \\
60^{\circ} \mathrm{mm} \text { year }^{-1}\end{array}$ & $\begin{array}{l}\text { Along sub. inter. } \\
45^{\circ} \mathrm{mm} \mathrm{year}^{-1}\end{array}$ \\
\hline \multirow{4}{*}{$\begin{array}{l}\mathbb{D}_{\infty} \\
\tilde{\Xi}_{\infty}\end{array}$} & Group 1 & $\sim 38 \mathrm{Ma}$ & 0.9 & 1.1 & 1.3 \\
\hline & Group 1 & $\sim 46 \mathrm{Ma}$ & 1.2 & 1.4 & 1.7 \\
\hline & Group 3 & $\sim 38 \mathrm{Ma}$ & 2.7 & 3.1 & 3.8 \\
\hline & Group 3 & $\sim 46 \mathrm{Ma}$ & 5.1 & 5.9 & 7.2 \\
\hline \multirow{2}{*}{ 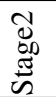 } & INT-EXT & $\sim 38 \mathrm{Ma}$ & 4 & - & - \\
\hline & INT-EXT & $\sim 46 \mathrm{Ma}$ & 1.6 & - & - \\
\hline
\end{tabular}

A counterclockwise $P-T$ path is proposed here for the EC. This trajectory is based on the results of garnet and chloritewhite mica modelling. The path as shown in Fig. 11 implies that, under nearly isobaric conditions, this area of the EC experienced cooling by $100-150^{\circ}$, possibly related to the entry of cold material into the subduction channel, as already proposed by Pognante (1989) for the southern Sesia Zone. Piemonte-Liguria oceanic units are a likely source of such material, which would be in line with age data of 58-40 Ma for the HP metamorphism in the Zermatt-Saas Zone (e.g. Rubatto et al., 1998; de Meyer et al., 2014; Weber et al., 2015) and with tectonic-kinematic models for the evolution of the Sesia-Dent Blanche nappes (Angiboust et al., 2014; Manzotti et al., 2014).

Summarizing, the major differences between the eclogite facies conditions recorded in the IC and the epidote blueschist facies conditions in the EC are now quantitatively constrained by $P-T-t$ data presented in this study (Fig. 11). Tectonic juxtaposition of these two complexes appears to have occurred during exhumation probably at $0.7-0.9 \mathrm{GPa}$ and $350-400{ }^{\circ} \mathrm{C}$ since these are the first joint $P-T$ conditions found in both complexes around 46-38 Ma (age data from Inger et al., 1996, and Reddy et al., 1999). These data confirm the proposition by Williams and Compagnoni (1983) of a first-order tectonic contact (Barmet Shear Zone in Giuntoli and Engi, 2016; Fig. 1b, c) between the two complexes. Our data are the first to quantify the $P-T$ discontinuity at that contact, i.e. $\sim 1 \mathrm{GPa}$ and $100-180^{\circ} \mathrm{C}$. This age range is younger compared to the age range proposed in the tectonic model by Angiboust et al. (2014) for the juxtaposition of the two complexes (70-57 Ma, based on data of Babist et al., 2006; Konrad-Schmolke et al., 2011; and Halama et al., 2014). Whereas Angiboust et al. (2014) considered the Tallorno-Chiusella Shear Zone (Babist et al., 2006; KonradSchmolke et al., 2011) to represent the contact between the IC and EC, more recent mapping (Giuntoli and Engi, 2016) shows that this contact is located several kilometres further NW, in the Barmet Shear Zone.

The data shown in Fig. 11 allow us to derive average exhumation rates for the IC (Table 6). Using Groups 1 and 3 as the two anchors, i.e. the oldest and the youngest groups, a first calculation considers Stage1, the interval from the highest pressures recorded in these two groups $(\sim 1.6 \mathrm{GPa}$ at $\sim 73 \mathrm{Ma}$ and $\sim 2 \mathrm{GPa}$ at $\sim 55 \mathrm{Ma})$ to the greenschist conditions upon juxtaposition with the $\mathrm{EC}(\sim 0.6 \mathrm{GPa}$ at $\sim 38 \mathrm{Ma}$, age from Inger et al., 1996). The mean vertical exhumation velocity obtained ranges from 0.9 to $2.7 \mathrm{~mm}$ year $^{-1}$ (Table 6). If we take the juxtaposition to be at $\sim 46 \mathrm{Ma}$ (Reddy et al., 1999) for the same $P$ conditions, values for the mean vertical exhumation velocity increase to 1.2 and $5.1 \mathrm{~mm}$ year $^{-1}$. Plate convergence between Adria and Europe was $\sim 15 \mathrm{mmyear}^{-1}$ in the time span of $68-38 \mathrm{Ma}$ (Handy et al., 2010). In the above calculations we considered subduction angles of 90,60 , and $45^{\circ}$ and a thickness of $20 \mathrm{~km}$ for the upper crust and $10 \mathrm{~km}$ for the lower crust; their densities were taken as 2.7 and $3.0 \mathrm{~g} \mathrm{~cm}^{-3}$, respectively, and $3.3 \mathrm{~g} \mathrm{~cm}^{-3}$ for the upper mantle.

For Stage2, the final stage of exhumation of the IC and EC, we obtained mean vertical exhumation velocities using the juxtaposition conditions $(\sim 0.6 \mathrm{GPa})$ and ages quoted for the end of Stage 1 and $32.5 \mathrm{Ma}$ for the arrival at the surface. That age of the Biella Volcanic Suite (Kapferer, 2010; Kapferer et al., 2012) is supported by zircon fission track ages (Berger et al., 2012). Depending on the time of juxtaposition adopted, at 38 or $46 \mathrm{Ma}$ (Table 6), a mean vertical exhumation velocity of 4 or $1.6 \mathrm{~mm} \mathrm{year}^{-1}$ results. For Stage2, only the vertical exhumation velocity was computed, and an average density of $2.7 \mathrm{~g} \mathrm{~cm}^{-3}$ was assumed. The rate of convergence in the 35-20 Ma period was $\sim 13 \mathrm{~mm}_{\text {year }}{ }^{-1}$ (Handy et al., 2010). Data for Stage 2 are taken as an approximate range of exhumation rates since the last part of the exhumation was not uniform throughout the Sesia Zone; owing to brittle structures local differences may be important (e.g. Berger et al., 2012; Malusà et al., 2006). Furthermore, the values given are minimum exhumation velocities, as the emplacement of the Biella Volcanic Suite may have post-dated the arrival of the Sesia Zone at the surface.

The Stage1 exhumation rates we obtained for the IC agree with exhumation velocities proposed for the same complex by Zucali et al. (2002) and Regis et al. (2014) and the mean exhumation rates for the Sesia Zone proposed by Roda et al. (2012). However, our rates are up to an order of magni- 
tude lower than those proposed by Rubatto et al. (2011) and the maximum values of Roda et al. (2012). Mean exhumation velocities for the final exhumation stage of the Sesia Zone (Stage2) are in the same range $\left(1.6-4 \mathrm{~mm}_{\text {year }}{ }^{-1}\right)$ as those for Stage1 (0.9-5.1 $\left.\mathrm{mm}_{\text {year }}{ }^{-1}\right)$. Our data show no decrease in exhumation velocity from early exhumation (i.e. mantle to deep crustal positions) to late stages (i.e. crustal levels to the surface), such as has been proposed by Rubatto and Hermann (2001) for ultra-HP terranes.

\subsection{Implication for the subduction, assembly, and exhumation of continental fragments}

Our work highlights that subducted continental terranes can be composed of several complexes that experienced major differences in their subduction histories (i.e. $\sim 1 \mathrm{GPa}$ in pressure and $100-180^{\circ} \mathrm{C}$ in temperature for the Sesia Zone). These complexes could have been tectonically juxtaposed during late metamorphic stages (i.e. greenschist facies conditions) before being jointly exhumed to the surface. Complexes can be lithologically heterogeneous and may comprise several tectono-metamorphic subunits (from a few hundred metres to several kilometres in thickness). These may experience similar $P-T$ paths but at different times (5-10 Myr apart). Differences in the $P-T-t$ trajectories would thus reflect different tectonic sheets and attest to tectonic mobility in the subduction zone and/or several stages of internal deformation plus hydration at eclogite facies that triggered a pervasive HP fabric and assemblage (including datable accessory minerals).

To unravel such complex histories in subducted continental terranes, carefully established field relations, followed by microstructural and petrochronological analysis need to be combined to

- map and identify the major and secondary tectonometamorphic contacts;

- characterize the different fabrics and the mineral phases defining them;

- quantify the differences existing in $P, T$, and $t$ for each complex or subunit.

Finally, the heterogeneity of subducted continental terranes highlighted by this study should be considered when comparing results to numerical and analogue models that aim to investigate the mechanisms responsible for the subduction and exhumation of the continental crust.

\section{Conclusions}

The present paper provides $P-T-t$ data for the central Sesia Zone, documenting in particular when and under what conditions the two main complexes of this HP terrain were juxtaposed during the Alpine orogenic cycle.

In particular, our data indicate the following.
- In the Internal Complex the main stages of mineral growth, and probably the attendant deformation, are related to eclogite facies conditions occurring between 77 and $55 \mathrm{Ma}$ and triggered by repeated influx of external fluid. It is during this subduction phase that most of the Permian HT assemblages were replaced, leaving only sparse relics of essentially dry granulites.

- The Internal Complex encompasses three groups of the samples studied, probably reflecting different tectonic sheets. These experienced similar internal deformation and $P-T$ paths, but at different times, reflecting minor (kilometre-scale) adjustments in the subduction channel at 50-60 km depth and were probably juxtaposed during final subduction-early exhumation stages.

- Comparing the two main complexes, diverse metamorphic evolutions emerge between 77 and $55 \mathrm{Ma}$, with conditions of $1.6-2 \mathrm{GPa}$ and $600-670^{\circ} \mathrm{C}$ in the Internal Complex, whereas only $0.7-0.9 \mathrm{GPa}$ and $\sim 500^{\circ} \mathrm{C}$ appear to have been reached in the External Complex.

- The two complexes were juxtaposed between 46 and $38 \mathrm{Ma}$ (Inger et al., 1996; Reddy et al., 1999) at $\sim 0.8 \mathrm{GPa}$ and $350^{\circ} \mathrm{C}$, so at mid-crustal levels during exhumation.

- The different tectonic sheets of the Internal Complex were initially exhumed with mean vertical velocities of 0.9-5.1 $\mathrm{mm}_{\text {year }}{ }^{-1}$ during Stage1, from the highest pressures recorded to the greenschist facies conditions attained upon juxtaposition with the External Complex.

- During Stage2, the final exhumation of the entire Sesia Zone occurred with mean vertical velocities between 1.6 and $4 \mathrm{~mm}$ year $^{-1}$, but the late stages of exhumation in the area can display local differences (Malusà et al., 2006; Berger et al., 2012).

This case study shows that subducted HP continental terranes can be composed of various complexes, characterized by major differences in their tectono-metamorphic histories, juxtaposed during exhumation by tectonic contacts operating under greenschist facies conditions. Such complexes include several subunits, which in the present case were some hundred metres to a few kilometres in thickness, that acted as fragments in the subduction zone, recording slightly different $P-T-t$ paths. The development of the main fabrics under eclogite facies conditions appears to have been triggered by external fluid influx. These processes could be dated based on the coeval growth of allanite and zircon. Petrochronology proved to be a powerful tool to quantify processes and unravel the metamorphic evolution in a complex geological setting, essentially because the detailed analytical work on the microscale could be linked to solid field evidence. 
Data availability. Original data underlying the material presented are available by contacting the authors.

\section{The Supplement related to this article is available online at https://doi.org/10.5194/se-9-191-2018-supplement.}

Competing interests. The authors declare that they have no conflict of interest.

Acknowledgements. This work was financially supported by the Swiss National Science Foundation (project 200020-146175). We thank Roberto Compagnoni, Daniele Regis, and Jörg Hermann for fruitful discussions. We acknowledge constructive comments and suggestions from Samuel Angiboust and the anonymous referee, and we are grateful to Patrice Rey for editorial handling.

Edited by: Patrice Rey

Reviewed by: Samuel Angiboust and one anonymous referee

\section{References}

Angiboust, S., Glodny, J., Oncken, O., and Chopin, C.: In search of transient subduction interfaces in the Dent Blanche-Sesia Tectonic System (W. Alps), Lithos, 205, 298-321, 2014.

Angiboust, S., Yamato, P., Hertgen, S., Hyppolito, T., Bebout, G. E., and Morales, L.: Fluid pathways and high?P metasomatism in a subducted continental slice (Mt. Emilius klippe, W. Alps), J. Metamorph. Geol., 35, 471-492, 2017.

Austrheim, H.: Eclogitization of lower crustal granulites by fluid migration through shear zones, Earth Planet. Sc. Lett., 81, 221232, https://doi.org/10.1016/0012-821X(87)90158-0, 1987.

Babist, J., Handy, M. R., Hammerschmidt, K., and KonradSchmolke, M.: Precollisional, multistage exhumation of subducted continental crust: The Sesia Zone, western Alps, Tectonics, 25, TC6008, https://doi.org/10.1029/2005TC001927, 2006.

Beltrando, M., Compagnoni, R., and Lombardo, B.: (Ultra-) Highpressure metamorphism and orogenesis: An Alpine perspective, Gondwana Res., 18, 147-166, 2010.

Berger, A., Mercolli, I., Kapferer, N., and Fügenschuh, B.: Single and double exhumation of fault blocks in the internal SesiaLanzo Zone and the Ivrea-Verbano Zone (Biella, Italy), Int. J. Earth Sci., 101, 1877-1894, 2012.

Berman, R. G.: Internally consistent thermodynamic data for minerals in the system $\mathrm{Na}_{2} \mathrm{O}-\mathrm{K}_{2} \mathrm{O}-\mathrm{CaO}-\mathrm{MgO}-\mathrm{FeO}-\mathrm{Fe}_{2} \mathrm{O}_{3}-\mathrm{Al}_{2} \mathrm{O}_{3}-$ $\mathrm{SiO}_{2}-\mathrm{TiO}_{2}-\mathrm{H}_{2} \mathrm{O}-\mathrm{CO}_{2}$, J. Petrol., 29, 445-522, 1988.

Berman, R. G.: Mixing properties of Ca-Mg-Fe-Mn garnets, Am. Mineral., 75, 328-344, 1990.

Bertolani, M.: Contributo allo studio petrografico della cosiddetta "formazione dioritico-kinzigitica"; Ricerche in Val Sabbiola (Valsesia), Rendiconti della Società Mineralogica Italiana, 10, 92-207, 1954.

Bertolani, M.: La formazione basica "Ivrea-Verbano" e la sua posizione nel quadro geologico-petrografico della bassa Val Sesia e del Biellese, Period. Mineral., 28, 151-209, 1959.
Brun, J.-P. and Faccenna, C.: Exhumation of high-pressure rocks driven by slab rollback, Earth Planet. Sc. Lett., 272, 1-7, 2008.

Bucher, K., Fazis, Y., Capitani, C. D., and Grapes, R.: Blueschists, eclogites, and decompression assemblages of the Zermatt-Saas ophiolite: High-pressure metamorphism of subducted Tethys lithosphere, Am. Mineral., 90, 821-835, 2005.

Buick, I. and Holland, T.: The PTt path associated with crustal extension, Naxos, Cyclades, Greece, Geol. Soc. Spec. Publ., 43, 365-369, 1989.

Burn, M.: LA-ICP-QMS Th-U/Pb allanite dating: methods and applications, PhD thesis, University of Bern, Bern, Switzerland, 2016.

Burn, M., Lanari, P., Pettke, T., and Engi, M.: Non-matrix-matched standardisation in LA-ICP-MS analysis: General approach and application to allanite Th-U-Pb age-dating, J. Anal. Atom. Spectrom., 32, 1359-1377, 2017.

Bussy, F., Venturini, G., Hunziker, J., and Martinotti, G.: U-Pb ages of magmatic rocks of the western Austroalpine Dent-BlancheSesia unit, Schweiz. Miner. Petrog., 78, 163-168, 1998.

Carraro, F., Dal Piaz, G. V., and Sacchi, R.: Serie di Valpelline e II Zona Diorito-Kinzigitica sono i relitti di un ricoprimento proveniente dalla Zona Ivrea-Verbano, Memorie della Società Geologica Italiana, 9, 197-224, 1970.

Compagnoni, R., Dal Piaz, G., Hunziker, J., Gosso, G., Lombardo, B., and Williams, P.: The Sesia-Lanzo Zone, a slice of continental crust with Alpine high pressure-low temperature assemblages in the Western Italian Alps, Rend. Soc. Ital. Mineral. Petrol, 33, 281-334, 1977.

Compagnoni, R., Engi, M., and Regis, D.: Valle d'Aosta section of the Sesia Zone: multi-stage HP metamorphism and assembly of a rifted continental margin, ISPRA, Soc. Geol. Italiana, Geol. Field Trips, 6, 1-44, https://doi.org/10.3301/GFT.2014.02, 2014.

Dal Piaz, G. V.: The Austroalpine-Piedmont nappe stack and the puzzle of the Alpine Tethys, Mem. Sci. Geol., 51, 155-176, 1999.

Dal Piaz, G. V., Gosso, G., and Martinotti, G.: La II Zona DioritoKinzigitica tra la Valle Sesia e la Valle d'Ayas (Alpi Occidentali), Memorie della Società Geologica Italiana, 11, 433-460, 1971.

Dal Piaz, G. V., Hunziker, J. C., and Martinotti, G.: La Zona SesiaLanzo e l'evoluzione tettonico-metamorfica delle Alpi nordoccidentali interne, Memorie della Società Geologica Italiana, 11, 433-466, 1972.

de Capitani, C. and Brown, T. H.: The computation of chemical equilibrium in complex systems containing non-ideal solutions, Geochim. Cosmochim. Acta, 51, 2639-2652, 1987.

de Capitani, C. and Petrakakis, K.: The computation of equilibrium assemblage diagrams with Theriak/Domino software, Am. Mineral., 95, 1006-1016, https://doi.org/10.2138/am.2010.3354, 2010.

de Meyer, C. M., Baumgartner, L. P., Beard, B. L., and Johnson, C. $\mathrm{M} . \mathrm{Rb}-\mathrm{Sr}$ ages from phengite inclusions in garnets from high pressure rocks of the Swiss Western Alps, Earth Planet. Sc. Lett., 395, 205-216, 2014.

Dewey, J., Helman, M., Knott, S., Turco, E., and Hutton, D.: Kinematics of the western Mediterranean, Geol. Soc. Spec. Publ., 45, 265-283, 1989.

Donaldson, D. G., Webb, A. A. G., Menold, C. A., KylanderClark, A. R., and Hacker, B. R.: Petrochronology of Himalayan ultrahigh-pressure eclogite, Geology, 41, 835-838, 2013. 
Dubacq, B., Vidal, O., and De Andrade, V.: Dehydration of dioctahedral aluminous phyllosilicates: thermodynamic modelling and implications for thermobarometric estimates, Contrib. Mineral. Petr., 159, 159-174, 2010.

Engi, M.: Petrochronology based on REE-minerals: monazite, allanite, xenotime, apatite, Rev. Mineral. Geochem., 83, 365-418, 2017.

Engi, M., Lanari, P., and Kohn, M. J.: Significant Ages - An Introduction to Petrochronology, Reviews Mineral. Geochem., 83, 1-12, 2017.

Engi, M., Giuntoli, F., Lanari, P., Burn, M., Kunz, B. E., and Bouvier, A.-S.: Pervasive eclogitization due to brittle deformation and rehydration of subducted basement, Effects on continental recycling?, Geochem. Geophy. Geosy., in press, 2018.

Erambert, M. and Austrheim, H.: The effect of fluid and deformation on zoning and inclusion patterns in poly-metamorphic garnets, Contrib. Mineral. Petr., 115, 204-214, 1993.

Etheridge, M., Wall, V., and Vernon, R.: The role of the fluid phase during regional metamorphism and deformation, J. Metamorph. Geol., 1, 205-226, 1983.

Evans, T. P.: A method for calculating effective bulk composition modification due to crystal fractionation in garnet-bearing schist; implications for isopleth thermobarometry, J. Metamorph. Geol., 22, 547-557, 2004.

Ewing, T. A., Hermann, J., and Rubatto, D.: The robustness of the Zr-in-rutile and Ti-in-zircon thermometers during high-temperature metamorphism (Ivrea-Verbano Zone, northern Italy), Contrib. Mineral. Petr., 165, 757-779, 2013.

Faccenda, M., Minelli, G., and Gerya, T.: Coupled and decoupled regimes of continental collision: numerical modeling, Earth Planet. Sc. Lett., 278, 337-349, 2009.

Foster, G., Parrish, R. R., Horstwood, M. S., Chenery, S., Pyle, J., and Gibson, H.: The generation of prograde $P-T-t$ points and paths; a textural, compositional, and chronological study of metamorphic monazite, Earth Planet. Sc. Lett., 228, 125-142, 2004.

Fuhrman, M. L. and Lindsley, D. H.: Ternary-feldspar modeling and thermometry, Am. Mineral., 73, 201-216, 1988.

Gasser, D., Bruand, E., Rubatto, D., and Stüwe, K.: The behaviour of monazite from greenschist facies phyllites to anatectic gneisses: An example from the Chugach Metamorphic Complex, southern Alaska, Lithos, 134, 108-122, 2012.

Giuntoli, F. and Engi, M.: Internal geometry of the central Sesia Zone (Aosta Valley, Italy): HP tectonic assembly of continental slices, Swiss J. Geosci., 109, 445-471, 2016.

Giuntoli, F., Lanari, P., and Engi, M.: Deeply subducted continental fragments - Part 1: Fracturing, dissolution-precipitation, and diffusion processes recorded by garnet textures of the central Sesia Zone (western Italian Alps), Solid Earth, 9, 167-189, https://doi.org/10.5194/se-9-167-2018, 2018.

Gregory, C. J., Rubatto, D., Allen, C. M., Williams, I. S., Hermann, J., and Ireland, T.: Allanite micro-geochronology: a LA-ICP-MS and SHRIMP U-Th-Pb study, Chem. Geol., 245, 162-182, 2007.

Halama, R., Konrad-Schmolke, M., Sudo, M., Marschall, H. R., and Wiedenbeck, M.: Effects of fluid-rock interaction on 40 $\mathrm{Ar} / 39 \mathrm{Ar}$ geochronology in high-pressure rocks (Sesia-Lanzo Zone, Western Alps), Geochim. Cosmochim. Acta, 126, 475494, 2014.
Handy, M. R., Schmid, S. M., Bousquet, R., Kissling, E., and Bernoulli, D.: Reconciling plate-tectonic reconstructions of Alpine Tethys with the geological-geophysical record of spreading and subduction in the Alps, Earth-Sci. Rev., 102, 121-158, 2010 .

Horstwood, M. S., Košler, J., Gehrels, G., Jackson, S. E., McLean, N. M., Paton, C., Pearson, N. J., Sircombe, K., Sylvester, P., and Vermeesch, P.: Community-Derived Standards for LA-ICP-MS U-(Th-) Pb Geochronology-Uncertainty Propagation, Age Interpretation and Data Reporting, Geostand. Geoanal. Res., 40, $311-$ 332, 2016.

Hunziker, P.: The stability of tri-octahedral Fe2+-Mg-Al chlorite: A combined experimental and theoretical study, MineralogischPetrographisches Institut der Universität, $\mathrm{PhD}$ thesis, University of Basel, Switzerland, 2003.

Hurford, A. J. and Hunziker, J.: Alpine cooling history of the Monte Mucrone eclogites (Sesia-Lanzo zone): fission track evidence, Schweiz. Miner. Petrog., 65, 325-334, 1985.

Hurford, A., Flisch, M., and Jäger, E.: Unravelling the thermotectonic evolution of the Alps: a contribution from fission track analysis and mica dating, Geol. Soc. Spec. Publ., 45, 369-398, 1989.

Hurford, A. J., Hunziker, J. C., and Stöckhert, B.: Constraints on the late thermotectonic evolution of the western Alps: evidence for episodic rapid uplift, Tectonics, 10, 758-769, 1991.

Inger, S., Ramsbotham, W., Cliff, R. A., and Rex, D. C.: Metamorphic evolution of the Sesia-Lanzo Zone, Western Alps: Time constraints from multi-system geochronology, Contrib. Mineral. Petr., 126, 152-168, 1996.

Jackson, S. E., Pearson, N. J., Griffin, W. L., and Belousova, E. A.: The application of laser ablation-inductively coupled plasmamass spectrometry to in situ U-Pb zircon geochronology, Chem. Geol., 211, 47-69, 2004.

Janots, E., Engi, M., Berger, A., Allaz, J., Schwarz, J.-O., and Spandler, C.: Prograde metamorphic sequence of REE-minerals in pelitic rocks of the Central Alps: implications for allanitemonazite-xenotime phase relations from 250 to $610^{\circ} \mathrm{C}$, J. Metamorph. Geol., 26, 509-526, https://doi.org/10.1111/j.15251314.2008.00774.x, 2008.

Janots, E., Engi, M., Rubatto, D., Berger, A., and Gregory, C.: Metamorphic rates in collisional orogeny from in situ allanite and monazite dating, Geology, 37, 11-14, https://doi.org/10.1130/G25192A.1, 2009.

Kapferer, N.: The evolution of the surface of the Sesia-Lanzo zone in Oligocene-Miocene times (Biella, NW Italy), PhD thesis, University of Bern, Bern, Switzerland, 2010.

Kapferer, N., Mercolli, I., Berger, A., Ovtcharova, M., and Fügenschuh, B.: Dating emplacement and evolution of the orogenic magmatism in the internal Western Alps: 2. The Biella Volcanic Suite, Swiss J. Geosci., 105, 67-84, 2012.

Keller, L. M., de Capitani, C., and Abart, R.: A quaternary solution model for white micas based on natural coexisting phengite-paragonite pairs J. Petrol., 46, https://doi.org/10.1093/petrology/egi050, 2005.

Keppie, D. F., Currie, C. A., and Warren, C.: Subduction erosion modes: comparing finite element numerical models with the geological record, Earth Planet. Sc. Lett., 287, 241-254, 2009. 
Konrad-Schmolke, M. and Halama, R.: Combined thermodynamicgeochemical modeling in metamorphic geology: Boron as tracer of fluid-rock interaction, Lithos, 208, 393-414, 2014.

Konrad-Schmolke, M., O’Brien, P. J., de Capitani, C., and Carswell, D. A.: Garnet growth at high- and ultra-high pressure conditions and the effect of element fractionation on mineral modes and composition, Lithos, 103, 309-332, 2008.

Konrad-Schmolke, M., O’Brien, P. J., and Zack, T.: Fluid migration above a subducted slab - Constraints on amount, pathways and major element mobility from partially overprinted eclogitefacies rocks (Sesia Zone, Western Alps), J. Petrol., 52, 457-486, https://doi.org/10.1093/petrology/egq087, 2011.

Kunz, B. E., Manzotti, P., von Niederhäusern, B., Engi, M., Darling, J. R., Giuntoli, F., and Lanari, P.: Permian high-temperature metamorphism in the Western Alps (NW Italy), Int. J. Earth Sci., 1-27, https://doi.org/10.1007/s00531-017-1485-6, 2017.

Kylander-Clark, A., Hacker, B., and Mattinson, J.: Slow exhumation of UHP terranes: titanite and rutile ages of the Western Gneiss Region, Norway, Earth Planet. Sc. Lett., 272, 531-540, 2008.

Lanari, P.: Micro-cartographie $P-T-e$ dans les roches métamorphiques. Applications aux Alpes et à l'Himalaya, Doctorate, Université de Grenoble, Grenoble, France, 534 pp., 2012.

Lanari, P. and Engi, M.: Local Bulk Composition Effects on Metamorphic Mineral Assemblages, Rev. Mineral. Geochem., 83, 55$102,2017$.

Lanari, P., Guillot, S., Schwartz, S., Vidal, O., Tricart, P., Riel, N., and Beyssac, O.: Diachronous evolution of the alpine continental subduction wedge: evidence from $P-T$ estimates in the Briançonnais Zone houillere (France - Western Alps), J. Geodyn., 56-57, 39-54, 2012.

Lanari, P., Riel, N., Guillot, S., Vidal, O., Schwartz, S., Pêcher, A., and Hattori, K. H.: Deciphering high-pressure metamorphism in collisional context using microprobe mapping methods: Application to the Stak eclogitic massif (northwest Himalaya), Geology, 41, 111-114, 2013.

Lanari, P., Vidal, O., Lewin, E., Dubacq, B., De Andrade, V., and Schwartz, S.: XMapTools a Matlab@-based graphic user interface for microprobe quantified image processing, Computers and Geosciences, 62, 227-240, https://doi.org/10.1016/j.cageo.2013.08.010, 2014.

Lanari, P., Giuntoli, F., Loury, C., Burn, M., and Engi, M.: An inverse modeling approach to obtain $P-T$ conditions of metamorphic stages involving garnet growth and resorption, Eur. J. Mineral., 29, 181-199, https://doi.org/10.1127/ejm/2017/0029-2597, 2017.

Lardeaux, J. M. and Spalla, M. I.: From granulites to eclogites in the Sesia zone (Italian Western Alps): a record of the opening and closure of the Piedmont ocean, J. Metamorph. Geol., 9, 3559, 1991.

Liati, A. and Gebauer, D.: Constraining the prograde and retrograde PTt path of Eocene H P rocks by SHRIMP dating of different zircon domains: inferred rates of heating, burial, cooling and exhumation for central Rhodope, northern Greece, Contrib. Mineral. Petr., 135, 340-354, 1999.

Lippitsch, R., Kissling, E., and Ansorge, J.: Upper mantle structure beneath the Alpine orogen from high-resolution teleseismic tomography, J. Geophys. Res.-Sol., 108, 2376, https://doi.org/10.1029/2002JB002016, 2003.
Lyubetskaya, T. and Ague, J.: Modeling the magnitudes and directions of regional metamorphic fluid flow in collisional orogens, J. Petrol., 50, 1505-1531, 2009.

Mäder, U. K. and Berman, R. G.: Amphibole thermobarometry: a thermodynamic approach, Geological Survey of Canada, Ottawa, Canada, Paper 92-1E, 393-400, 1992.

Mäder, U. K., Percival, J. A., and Berman, R. G.: Thermobarometry of garnet-clinopyroxene-hornblende granulites from the Kapuskasing structural zone, Can. J. Earth Sci., 31, 1134-1145, 1994.

Malusà, M., Philippot, P., Zattin, M., and Martin, S.: Late stages of exhumation constrained by structural, fluid inclusion and fission track analyses (Sesia-Lanzo unit, Western European Alps), Earth Planet. Sc. Lett., 243, 565-580, 2006.

Malusà, M., Faccenna, C., Garzanti, E., and Polino, R.: Divergence in subduction zones and exhumation of high pressure rocks (Eocene Western Alps), Earth Planet. Sc. Lett., 310, 2132, 10.1016/j.eps1.2011.08.002, 2011.

Manzotti, P., Ballevre, M., Zucali, M., Robyr, M., and Engi, M.: The tectonometamorphic evolution of the Sesia-Dent Blanche nappes (internal Western Alps): review and synthesis, Swiss J. Geosci., 107, 309-336, 2014.

Meyre, C., de Capitani, C., and Partzsch, J. H.: A ternary solid solution model for omphacite and its application to geothermobarometry of eclogites from the middle Adula Nappe (Central Alps, Switzerland), J. Metamorph. Geol., 15, 687-700, 1997.

Mottram, C. M., Warren, C. J., Regis, D., Roberts, N. M., Harris, N. B., Argles, T. W., and Parrish, R. R.: Developing an inverted Barrovian sequence; insights from monazite petrochronology, Earth Planet. Sc. Lett., 403, 418-431, 2014.

Negro, F., Bousquet, R., Vils, F., Pellet, C.-M., and Hänggi-Schaub, J.: Thermal structure and metamorphic evolution of the PiemontLigurian metasediments in the northern Western Alps, Swiss J. Geosci., 106, 63-78, 2013.

Oliver, N.: Review and classification of structural controls on fluid flow during regional metamorphism, J. Metamorph. Geol., 14, 477-492, 1996.

Passchier, C. W., Urai, J. L., van Loon, J., and Williams, P. F.: Structural geology of the central Sesia Lanzo Zone, Geol. Mijnbouw, 60, 497-507, 1981.

Paton, C., Woodhead, J. D., Hellstrom, J. C., Hergt, J. M., Greig, A., and Maas, R.: Improved laser ablation U-Pb zircon geochronology through robust downhole fractionation correction, Geochem. Geophy. Geosys., 11, Q0AA06, https://doi.org/10.1029/2009GC002618, 2010.

Paton, C., Hellstrom, J., Paul, B., Woodhead, J., and Hergt, J.: Iolite: Freeware for the visualisation and processing of mass spectrometric data, J. Anal. Atom. Spectrom., 26, 2508-2518, 2011.

Peacock, S. M.: Thermal effects of metamorphic fluids in subduction zones, Geology, 15, 1057-1060, 1987.

Pennacchioni, G.: Progressive eclogitization under fluid-present conditions of pre-Alpine mafic granulites in the Austroalpine Mt Emilius Klippe (Italian western Alps), J. Struct. Geol., 18, 549561, 1996.

Petrus, J. A. and Kamber, B. S.: VizualAge: A novel approach to laser ablation ICP-MS U-Pb geochronology data reduction, Geostand. Geoanal. Res., 36, 247-270, 2012.

Pognante, U.: Tectonic implications of lawsonite formation in the Sesia zone (western Alps), Tectonophysics, 162, 219-227, 1989. 
Quick, J. E., Sinigoi, S., Snoke, A. W., Kalakay, T. J., Mayer, A., and Peressini, G.: Geologic map of the southern Ivrea-Verbano Zone, northwestern Italy, US Geological Survey, 2003.

Rebay, G. and Spalla, M. I.: Emplacement at granulite facies conditions of the Sesia-Lanzo metagabbros: an early record of Permian riftig?, Lithos, 58, 85-104, 2001.

Reddy, S., Wheeler, J., and Cliff, R.: The geometry and timing of orogenic extension: an example from the Western Italian Alps, J. Metamorph. Geol., 17, 573-590, 1999.

Regis, D., Rubatto, D., Darling, J., Cenki-Tok, B., Zucali, M., and Engi, M.: Multiple metamorphic stages within an eclogite-facies terrane (Sesia Zone, Western Alps) revealed by Th-U-Pb petrochronology, J. Petrol., 55, 1429-1456, https://doi.org/10.1093/petrology/egu029, 2014.

Replumaz, A., Negredo, A. M., Guillot, S., and Villaseñor, A.: Multiple episodes of continental subduction during India/Asia convergence: Insight from seismic tomography and tectonic reconstruction, Tectonophysics, 483, 125-134, 2010.

Rivalenti, G., Garuti, G., and Rossi, A.: The origin of the IvreaVerbano basic formation (western Italian Alps); whole rock geochemistry, Boll. Soc. Geol. Ital., 94, 1149-1186, 1975.

Roda, M., Spalla, M. I., and Marotta, A. M.: Integration of natural data within a numerical model of ablative subduction: a possible interpretation for the Alpine dynamics of the Austroalpine crust, J. Metamorph. Geol., 30, 973-996, 2012.

Root, D. B., Hacker, B., Mattinson, J., and Wooden, J. L.: Zircon geochronology and ca. $400 \mathrm{Ma}$ exhumation of Norwegian ultrahigh-pressure rocks: an ion microprobe and chemical abrasion study, Earth Planet. Sc. Lett., 228, 325-341, 2004.

Rosenbaum, G., Lister, G. S., and Duboz, C.: Relative motions of Africa, Iberia and Europe during Alpine orogeny, Tectonophysics, 359, 117-129, 2002.

Rubatto, D. and Hermann, J.: Exhumation as fast as subduction?, Geology, 29, 3-6, 2001.

Rubatto, D., Gebauer, D., and Fanning, M.: Jurassic formation and Eocene subduction of the Zermatt-Saas-Fee ophiolites: implications for the geodynamic evolution of the Central and Western Alps, Contrib. Mineral. Petr., 132, 269-287, 1998.

Rubatto, D., Regis, D., Hermann, J., Boston, K., Engi, M., Beltrando, M., and McAlpine, S.: Yo-Yo subduction recorded by accessory minerals (Sesia Zone, Western Alps), Nat. Geosci., 4, 338-342, https://doi.org/10.1038/ngeo1124, 2011.

Rubie, D. C.: The catalysis of mineral reactions by water and restrictions on the presence of aqueous fluid during metamorphism, Mineral. Mag., 50, 399-415, 1986.

Rudashevsky, N., Burakov, B., Lupal, S., and Thalhammer, O.: Liberation of accessory minerals from various rock types by electricpulse disintegration-method and application, T. I. Min. Metall. C., 104, C25-C28, 1995.

Schenk, V.: PTt path of the lower crust in the Hercynian fold belt of southern Calabria, Geol. Soc. Spec. Publ., 43, 337-342, 1989.

Schmid, S. M., Kissling, E., Diehl, T., van Hinsbergen, D. J., and Molli, G.: Ivrea mantle wedge, arc of the Western Alps, and kinematic evolution of the Alps-Apennines orogenic system, Swiss J. Geosci., 1-32, 2017.

Scott, D. J. and St-Onge, M. R.: Constraints on Pb closure temperature in titanite based on rocks from the Ungava orogen, Canada: Implications for $\mathrm{U}-\mathrm{Pb}$ geochronology and PTt path determinations, Geology, 23, 1123-1126, 1995.
Sláma, J., Košler, J., Condon, D. J., Crowley, J. L., Gerdes, A., Hanchar, J. M., Horstwood, M. S., Morris, G. A., Nasdala, L., and Norberg, N.: Plešovice zircon - a new natural reference material for $\mathrm{U}-\mathrm{Pb}$ and $\mathrm{Hf}$ isotopic microanalysis, Chem. Geol., 249, 1-35, 2008.

Stacey, J. T. and Kramers, J.: Approximation of terrestrial lead isotope evolution by a two-stage model, Earth Planet. Sc. Lett., 26, 207-221, 1975.

Stöckhert, B. and Gerya, T. V.: Pre-collisional high pressure metamorphism and nappe tectonics at active continental margins: a numerical simulation, Terra Nova, 17, 102-110, 2005.

Tao, W. C. and O'Connell, R. J.: Ablative subduction: A two-sided alternative to the conventional subduction model, J. Geophys. Res.-Sol., 97, 8877-8904, 1992.

Vavra, G., Gebauer, D., Schmid, R., and Compston, W.: Multiple zircon growth and recrystallization during polyphase Late Carboniferous to Triassic metamorphism in granulites of the Ivrea Zone (Southern Alps): An ion microprobe (SHRIMP) study, Contrib. Mineral. Petr., 122, 337-358, 1996.

Vavra, G., Schmid, R., and Gebauer, D.: Internal morphology, habit and $\mathrm{U} / \mathrm{Th} / \mathrm{Pb}$ microanalysis of amphibolite-to-granulite facies zircons: geochronology of the Ivrea Zone (Southern Alps), Contrib. Mineral. Petr., 134, 380-404, 1999.

Vidal, O., Parra, T., and Vieillard, P.: Thermodynamic properties of the Tschermak solid solution in Fe-chlorite: Application to natural examples and possible role of oxidation, Am. Mineral. 90, 347-358, 2005.

Vidal, O., De Andrade, V., Lewin, E., Munoz, M., Parra, T., and Pascarelli, S.: P-T-deformation- $\mathrm{Fe}^{3+} \mathrm{Fe}^{2+}$ mapping at the thin section scale and comparison with XANES mapping: application to a garnet-bearing metapelite from the Sambagawa metamorphic belt (Japan), J. Metamorph. Geol., 24, 669-683, 2006.

Vidal, O., Lanari, P., Munoz, M., Bourdelle, F., and De Andrade, V.: Deciphering temperature, pressure and oxygen-activity conditions of chlorite formation, Clay Miner., 51, 615-633, 2016.

Vitale Brovarone, A., Beyssac, O., Malavieille, J., Molli, G., Beltrando, M., and Compagnoni, R.: Stacking and metamorphism of continuous segments of subducted lithosphere in a high-pressure wedge: the example of Alpine Corsica (France), Earth-Sci. Rev., 116, 35-56, 2013.

Wagner, G. and Reimer, G.: Fission track tectonics: the tectonic interpretation of fission track apatite ages, Earth Planet. Sc. Lett., 14, 263-268, 1972.

Walther, J. V. and Orville, P. M.: Volatile production and transport in regional metamorphism, Contrib. Mineral. Petr., 79, 252-257, 1982.

Warren, C. J., Beaumont, C., and Jamieson, R. A.: Formation and exhumation of ultra-high-pressure rocks during continental collision: Role of detachment in the subduction channel, Geochem. Geophy. Geosys., 9, Q04019, https://doi.org/10.1029/2007GC001839, 2008.

Weber, S., Sandmann, S., Miladinova, I., Fonseca, R. O., Froitzheim, N., Münker, C., and Bucher, K.: Dating the initiation of Piemonte-Liguria Ocean subduction: Lu-Hf garnet chronometry of eclogites from the Theodul Glacier Unit (Zermatt-Saas zone, Switzerland), Swiss J. Geosci., 108, 183-199, 2015.

Wheeler, J. and Butler, R. W. H.: Evidence for extension in the western Alpine Orogen: the contact between the oceanic Piemonte 
and overlying continental Sesia units, Earth Planet. Sc. Lett., 117, 457-474, 1993.

Whitney, D. L. and Evans, B. W.: Abbreviations for names of rockforming minerals, Am. Mineral., 95, 185-187, 2010.

Williams, P. and Compagnoni, R.: Deformation and metamorphism in the Bard area of the Sesia Lanzo Zone, Western Alps, during subduction and uplift, J. Metamorph. Geol., 1, 117-140, 1983.

Yamato, P., Burov, E., Agard, P., Le Pourhiet, L., and Jolivet, L.: HP-UHP exhumation during slow continental subduction: Selfconsistent thermodynamically and thermomechanically coupled model with application to the Western Alps, Earth Planet. Sc. Lett., 271, 63-74, 2008.

Zhao, L., Paul, A., Guillot, S., Solarino, S., Malusà, M. G., Zheng, T., Aubert, C., Salimbeni, S., Dumont, T., and Schwartz, S.: First seismic evidence for continental subduction beneath the Western Alps, Geology, 43, 815-818, 2015.
Zingg, A.: The Ivrea and Strona Ceneri Zones (Southern Alps, Ticino and Northern Italy): A review., Schweiz. Miner. Petrog., 63, 361-392, 1983.

Zucali, M., Spalla, M. I., and Gosso, G.: Strain partitioning and fabric evolution as a correlation tool: the example of the Eclogitic Micaschists Complex in the Sesia-Lanzo Zone (Monte Mucrone-Monte Mars, Western Alps, Italy), Schweiz. Miner. Petrog., 82, 429-454, 2002.

Zucali, M. and Spalla, M. I.: Prograde lawsonite during the flow of continental crust in the Alpine subduction: Strain vs. metamorphism partitioning, a field-analysis approach to infer tectonometamorphic evolutions (Sesia-Lanzo Zone, Western Italian Alps), J. Struct. Geol., 33, 381-398, 2011. 